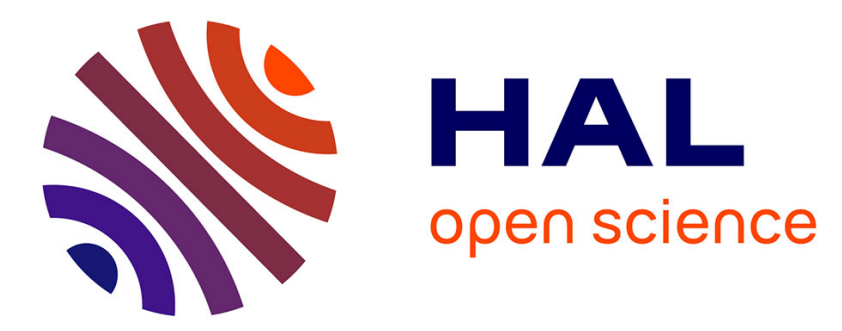

\title{
A 135,000-year Vostok-Specmap Common temporal framework
}

Todd Sowers, Michael Bender, Laurent Labeyrie, Doug Martinson, Jean Jouzel, Dominique Raynaud, Jean Jacques Pichon, Yevgeniy Sergeevich Korotkevich

\section{To cite this version:}

Todd Sowers, Michael Bender, Laurent Labeyrie, Doug Martinson, Jean Jouzel, et al.. A 135,000year Vostok-Specmap Common temporal framework. Paleoceanography, 1993, 8 (6), pp.737-766. 10.1029/93PA02328. hal-03334794

\section{HAL Id: hal-03334794 https://hal.science/hal-03334794}

Submitted on 5 Sep 2021

HAL is a multi-disciplinary open access archive for the deposit and dissemination of scientific research documents, whether they are published or not. The documents may come from teaching and research institutions in France or abroad, or from public or private research centers.
L'archive ouverte pluridisciplinaire HAL, est destinée au dépôt et à la diffusion de documents scientifiques de niveau recherche, publiés ou non, émanant des établissements d'enseignement et de recherche français ou étrangers, des laboratoires publics ou privés. 
PALEOCEANOGRAPHY, VOL. 8, NO. 6, PAGES 737-766, DECEMBER 1993

\section{A 135,000-YEAR VOSTOK-SPECMAP COMMON TEMPORAL FRAMEWORK}

Todd Sowers, 1 Michael Bender, 1,2

Laurent Labeyrie, 2 Doug Martinson, 3

Jean Jouzel,4,5 Dominique Raynaud, 6

Jean Jacques Pichon, 7 and

Yevgeniy Sergeevich Korotkevich8

\begin{abstract}
The object of the present study is to introduce a means of comparing the Vostok and marine chronologies. Our strategy has been to use the $\delta 18 \mathrm{O}$ of atmospheric $\mathrm{O}_{2}$ (denoted $\delta 18 \mathrm{O}_{\mathrm{atm}}$ ) from the Vostok ice core as a proxy for the $\delta 18 \mathrm{O}$ of seawater (denoted $\delta 18 \mathrm{O}_{\mathrm{sw}}$ ). Our underlying premise in using $\delta 18 \mathrm{O}_{\mathrm{atm}}$ as a proxy for $\delta 18 \mathrm{O}_{\mathrm{sw}}$ is that past variations in $\delta 18 \mathrm{O}_{\mathrm{sw}}$ (an indicator of continental ice volume) have been transmitted to the atmospheric $\mathrm{O}_{2}$ reservoir by photosynthesizing organisms in the
\end{abstract}

\footnotetext{
1Graduate School of Oceanography, University of Rhode Island, Narragansett.

2Centre des Faibles Radioactivites, Laboratorie Mixte CNRS-CEA, Gif Sur Yvette, France.

3Lamont-Doherty Earth Observatory Palisades, New

York.

4Laboratoire de Modelisation du Climat et de l'Environnement, Gif Sur Yvette Cedex, France.

5 Also at Laboratoire de Glaciologie et Geophysique de l'Environnement, St. Martin d'Heres Cedex, France.

6Laboratoire de Glaciologie et Geophysique de l'Environnement, St. Martin d'Heres Cedex, France. 7Department Géologie et Océanologie, Université Bordeaux, Talence Cedex France.

${ }^{8}$ Arctic and Antarctic Research Institute, St.

Petersburg, Russia.

Copyright 1993

by the American Geophysical Union.

Paper number 93PA02328.

0883-8305/93/93PA-02328 $\$ 10.00$
}

surface waters of the world's oceans. We compare our record of $\delta 18 \mathrm{O}_{\text {atm }}$ to the $\delta 18 \mathrm{O}_{\mathrm{sw}}$ record which has been developed from studies of the isotopic composition of biogenic calcite $\left(\boldsymbol{\delta} \mathbf{1 8 O}_{\mathrm{foram}}\right)$ in deepsea cores. We have tied our $\delta 18 \mathrm{O}_{\mathrm{atm}}$ record from Vostok to the SPECMAP timescale throughout the last $135 \mathrm{kyr}$ by correlating $\delta 18 \mathrm{O}_{\text {atm }}$ with a $\delta 18 \mathrm{O}_{\text {sw }}$ record from V19-30. Results of the correlation indicate that $77 \%$ of the variance is shared between these two records. We observed differences between the $\delta 18 \mathrm{O}_{\mathrm{atm}}$ and the $\delta 18 \mathrm{O}_{\mathrm{sw}}$ records during the coldest periods, which indicate that there have been subtle changes in the factors which regulate $\delta 18 \mathrm{O}_{\text {atm }}$ other than $\delta 18 \mathrm{O}_{\mathrm{sw}}$. Our use of $\delta 18 \mathrm{O}_{\mathrm{atm}}$ as a proxy for $\delta 18 \mathrm{O}_{\text {sw }}$ must therefore be considered tentative, especially during these periods. By correlating $\delta 18 \mathrm{O}_{\text {atm }}$ with $\delta 18 \mathrm{O}_{\mathrm{sw}}$, we provide a common temporal framework for comparing phase relationships between atmospheric records (from ice cores) and oceanographic records constructed from deep-sea cores. Our correlated age-depth relation for the Vostok core should not be considered an absolute Vostok timescale. We consider it to be the preferred timescale for comparing Vostok climate records with marine climate records which have been placed on the SPECMAP timescale. We have examined the fidelity of this common temporal framework by comparing sea surface temperature (SST) records from sediment cores with an Antarctic temperature record from the Vostok ice core. We have demonstrated that when the southern ocean SST and Antarctic temperature records are compared on this common temporal framework, they show a high degree of similarity. We interpret this result as supporting our use of the common temporal framework for comparing other climate records from 
the Vostok ice core with any climate record that has been correlated into the SPECMAP chronology.

\section{INTRODUCTION}

Studies of ice cores have supplied vast amounts of information about late Pleistocene climate.

Variations in the isotopic composition of the ice from Greenland and Antarctic ice cores have been used to construct temperature records for these sites [Dansgaard et al., 1985; Lorius et al., 1985; Hammer et al., 1986; Jouzel et al., 1987; Johnsen et al., 1992]. Other important records which have been constructed from ice core analyses include the composition of the paleoatmosphere [Neftel et al., 1988; Raynaud et al., 1988; Stauffer et al., 1988; Chappellaz et al., 1990; Barnola et al., 1991; Etheridge et al., 1992] and a record of aerosol transport to the ice sheets [Raisbeck et al., 1987; Petit et al., 1990].

The original chronology for the Vostok ice core was constructed using a two-dimensional rheologic model of the ice flow upstream from Vostok in conjunction with a record of the paleoaccumulation rate [Lorius et al., 1985]. The chronology for the trapped air parcels was derived by calculating a record of the ice age-gas age difference ( $\Delta$ age) [Barnola et al., 1987,1991] and subtracting it from the ice age versus depth relation of Lorius et al. [1985]. The approach adopted here is to correlate our record of the $\delta 18 \mathrm{O}$ of atmospheric $\mathrm{O}_{2}\left(\delta 18 \mathrm{O}_{\mathrm{atm}}\right)$ from Vostok with the $\delta 180$ of seawater $\left(\delta 18 \mathrm{O}_{\mathrm{sw}}\right)$ derived from studies of the $\delta 180$ of foraminiferal calcite. Our underlying premise in using $\delta 18 \mathrm{O}_{\mathrm{atm}}$ as a proxy for $\delta 18 \mathrm{O}_{\mathrm{sw}}$ is that past variations in $\delta 18 \mathrm{O}_{\mathrm{sw}}$ have been transmitted to the atmospheric $\mathrm{O}_{2}$ reservoir by photosynthesizing organisms in the surface waters of the world's oceans. We compare our record of $\delta 18 \mathrm{O}_{\mathrm{atm}}$ to the $\delta 18 \mathrm{O}_{\mathrm{sw}}$ record which has been developed from studies of the isotopic composition of biogenic calcite of benthic foraminifera $\left(\delta 18 \mathrm{O}_{\text {foram }}\right)$ in deep-sea cores [Labeyrie et al., 1987; Shackleton, 1987]. In making such a correlation we derive a direct estimate of a gas age versus depth relation for Vostok that is consistent with the marine chronostratigraphy. Our correlation provides the basis for a more direct comparison of the atmospheric $p \mathrm{CO}_{2}$ and $p \mathrm{CH}_{4}$ records from Vostok with climate records obtained from deep-sea sediment studies covering the last $140 \mathrm{kyr}$.

\section{ICE CORE AND DEEP-SEA CORE CHRONOSTRATIGRAPHIES}

\section{Deep-Sea Chronostratigraphies}

Most records of Pleistocene climate constructed from deep-sea cores can be placed into one of the two SPECMAP timescales (the lower-resolution long timescale [Imbrie et al., 1984] or the higherresolution short timescale [Martinson et al., 1987]). The stratigraphic bases for these timescales are the SPECMAP stacked $\delta 18 \mathrm{O}_{\text {foram }}$ records (long record [Prell et al., 1986] and short record [Pisias et al., 1984]) which allow direct transfer of the timescales through correlation with any other $\delta 18 \mathrm{O}_{\text {foram }}$ versus age records. The basis for these two SPECMAP chronologies is that variations in the Earth's orbital geometry influence incoming solar radiation which in tum forces, or at least paces, variations in the size of the continental ice sheets [Hays et al., 1976a; Imbrie et al., 1984]. The higher-resolution short SPECMAP chronology (used here) was constructed using four different "tuning" strategies involving five proxy climate indicators (including the $\delta 18 \mathrm{O}_{\text {foram }}$ record) from RC11-120 [Hays et al., 1976a,b] (Figure 1) as well as the SPECMAP stacked $\delta 18 O_{\text {foram }}$ record [Pisias et al., 1984]. Errors in this timescale, estimated using various climate indicators, deep sea cores, and tuning strategies, average $\pm 3.5 \mathrm{kyr}$ and range from 1 to $7 \mathrm{kyr}$. The short SPECMAP timescale has also served as the basis for correlating other records such as the China loess deposits [Kukla and An, 1989; Hovan et al., 1991] and pollen records from North America and Europe [Guiot et al., 1989].

\section{Ice Core Chronostratigraphies}

Dating ice cores retrieved from the East Antarctic plateau has proven difficult because of the lack of annual stratigraphic layers in the ice. Lorius et al. [1985] established a timescale for the Vostok ice core with the use of a two-dimensional ice flow model. Their approach utilized a record of the paleoaccumulation rate in conjunction with model calculations of the degree to which annual layers have been thinned during transport within the East Antarctic ice sheet (commonly referred to as the thinning function). Recent sensitivity studies suggest that an ice age-depth profile for an ice core is largely dependent on the paleoaccumulation record used [Ritz, 1992]. The original Vostok chronology was constructed by assuming that the accumulation rate upstream from Vostok was directly related to the $\delta \mathrm{D}$ or $\delta 180$ of the precipitation. This assumption was later supported by 10Be measurements [Yiou et al., 1985; Raisbeck et al., 1987; Jouzel et al., 1989; Raisbeck et al., 1992]. On the other hand, the average $\delta D_{\text {ice }}$ from the Dome B core (located $~ 300$ $\mathrm{km}$ upstream from Vostok) during the Holocene is $7 \%$ higher than that for the Holocene section of the Vostok ice core [Kotlyakov, 1990]. The end of the last glacial-interglacial transition $(\sim 10 \mathrm{ka})$ is about $140 \mathrm{~m}$ deeper at Dome $B$ than at Vostok. The inferred accumulation rate at Dome $B$ over this period is thus $60 \%$ higher than at Vostok. This result is much higher than the $10 \%$ difference which would be derived from the difference between the $\delta D_{\text {ice }}$ 


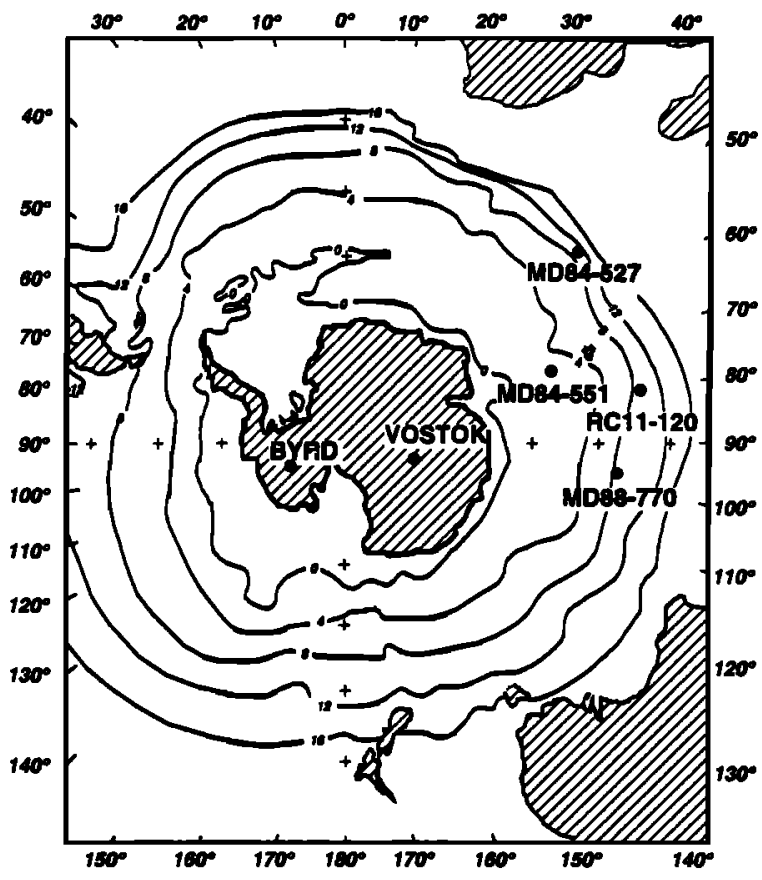

Fig. 1. Index map showing the location of the deepsea sediment core (MD88-770, 460, $96^{\circ} \mathrm{E}$ ) as well as the Antarctic ice cores included in our study. Also plotted are the summer sea surface temperature isotherms for the southern ocean.

values of the ice at the two sites. Ritz [1992] concluded from this observation that the accumulation rate near Vostok is not solely controlled by the temperature of the inversion layer. Other factors, such as the orographic and radiative cooling appear to significantly influence the accumulation rate over East Antarctica (C. Ritz, Chronology of the Vostok ice core based on precipitation and ice flow modeling, submitted to Journal of Glaciology, 1993). Furthermore, Jouzel et al. [1992] showed that, when the same glaciological model was applied to both the Vostok and Dome $\mathrm{C}$ cores, the timing of the minimum in the dust flux near the beginning of the last glacial termination at the two sites was different by about $1 \mathrm{kyr}$. These results have been incorporated into a revised flow model for the Vostok area which now extends to 2546 meters below the surface [Jouzel et al., 1993].

Minor modifications to the Lorius et al. [1985] Vostok chronology were proposed in three later studies. Jouzel et al. [1987] used a more detailed $\delta D_{\text {ice }}$ record in place of the $\delta 18 \mathrm{O}_{\text {ice }}$ record for estimating the inversion layer temperature above Vostok and the paleoaccumulation rate. They recalculated the Vostok age-depth curve based on the revised paleoaccumulation rates and found that the revised chronology agreed well with that of Lorius et al. [1985]. Petit et al. [1990] correlated the Vostok dust record with the magnetic susceptibility record from RC11-120 (taken to be a dust proxy). They suggested that the Lorius et al. [1985] age for the marine stage $5 e$ was about 10 kyr older than the SPECMAP age, and noted that ${ }^{230} \mathrm{Th} /{ }^{234} \mathrm{U}$ dating studies of corals favored the SPECMAP age [Bard et al., 1990b] (but see Lambeck and Nakada [1992] for another view). Finally, Pichon et al. [1992] compared a record of sea surface temperature (SST) from the southern ocean with the Vostok temperature record to derive a new age-depth curve for Vostok. Pichon et al. [1992] also suggested that the Lorius et al. [1985] age for stage 5e was about $6 \mathrm{kyr}$ older than the corresponding SPECMAP age.

The net result of these correlation studies is to propose various ice age-depth profiles for Vostok which are generally within the stated uncertainties of the original Lorius et al. [1985] chronology. The present work provides another method of correlating the Vostok and marine timescales. We emphasize that the goal of recent correlation studies by Petit et al. [1990], Shackleton et al. [1992], and Pichon et al. [1992] has been to place the Vostok climate records into the SPECMAP chronology. None of the correlation studies gives any indication about which absolute chronology is superior. In the next section we use our record of $\delta 18 \mathrm{O}_{\mathrm{atm}}$ to correlate the Vostok and SPECMAP timescales. We focus on developing a common timescale which is suitable for comparing the Vostok and marine climate records. The results from this study have no bearing on the absolute nature of the Vostok timescale itself. Finally, we compare our correlation results with previous correlations and discuss the implications for leads and lags within the climate system.

\section{COMPARING THE $\delta 180$ OF ATMOSPHERIC $\mathrm{O}_{2}$ WITH THE $\delta 180$ OF SEAWATER}

\section{A Record of the $818 O$ of SeaWater}

We have constructed a record of $\delta 18 \mathrm{O}_{\text {sw }}$ from the benthic $\delta 18 \mathrm{O}_{\text {foram }}$ record (Uvigerina senticosa) from V19-30 (3०21'S, 83०21'W, 3091-m water depth) [Shackleton and Pisias, 1985]. We chose the V19-30 core for two reasons. First, the $\delta 18 \mathrm{O}_{\text {foram }}$ record from this core was used in constructing the SPECMAP stacked record [Pisias et al., 1984]. Consequently, the SPECMAP age model was directly applied to this core during the development of the chronostratigraphy. Second, the long $\delta 180_{\text {foram }}$ record ( $>300 \mathrm{kyr}$ ) from this core provides a target curve for correlating $\delta 18 \mathrm{O}_{\mathrm{atm}}$ variations from deeper (yet to be drilled) sections of the Vostok core into the SPECMAP timescale. We have normalized the $\delta 18 \mathrm{O}_{\text {foram }}$ values by arbitrarily removing $3.46 \%$ o from all samples, so that the average Holocene $\delta 180_{\text {foram }}$ value is $0 \%$.

There are two factors which influence the foraminiferal $\delta 180$ record itself. The first is the 
$\delta 18 \mathrm{O}_{\mathrm{sw}}$, and the second is bottom-water temperature. To correct for bottom-water temperature changes, we have made the following assumptions: (1) glacial bottom waters were $1.7^{\circ} \mathrm{C}$ colder than interglacial temperatures [Chappell and Shackleton, 1986; Birchfield, 1987; Shackleton, 1987], (2) deep waters warmed during the terminations themselves and cooled during the transition from the last interglacial (stage 5e) to the glacial period (stage 5d), starting at about $120 \mathrm{ka}$ in the SPECMAP chronology

[Fairbanks and Matthews, 1978; Labeyrie et al., 1987; Shackleton, 1987], and (3) the temperature change occurred over a 5-kyr period centered within the terminations or 5e-5d boundary. To correct for these temperature variations, we subtract $0.4 \%$ from all glacial $\delta 18 \mathrm{O}_{\text {foram }}$ data [Shackleton and Opdyke, 1973] and apply the correction gradually over the 5kyr transition periods. The exact timing of the deepwater temperature changes within a transition is difficult to assess on a global scale. Given that the average length of the last two terminations is 10-12 kyr, our placement of the temperature changes in the middle of the transitions introduces a $1-3 \mathrm{kyr}$ uncertainty in the exact timing of the changes in deepwater temperature. This uncertainty is one limit on the accuracy of our common temporal framework for these periods.

\section{A Record of the $818 \mathrm{O}$ of Atmospheric $\mathrm{O}_{2}$ From the Vostok Ice Core}

We have measured the isotopic composition of trapped $\mathrm{O}_{2}$ and $\mathrm{N}_{2}$ from 95 discrete depths along the Vostok $3 \Gamma(2083 \mathrm{~m})$ and BH-1 (178 m) cores. Fossil air samples were extracted from 12- to $16-\mathrm{g}$ ice samples by allowing the ice samples to melt invacuo. The $\sim 1-\mathrm{cm}^{3}$ (STP) air sample was then quantitatively transferred to a stainless steel sample tube immersed in liquid helium. The air sample was then either equilibrated into a glass ampoule and sealed for later analysis or introduced directly into the sample reservoir of a Finnigan MAT 251 isotope ratio mass spectrometer where it was analyzed against an aliquot of dry air [Sowers et al., 1989, 1991]. We report our results using the delta notation, where the reference is the present day air:

$\delta^{18} \mathrm{O}_{\mathrm{O}_{2} \text { ice }}=\left\{\left[\frac{18 \mathrm{O} 16 \mathrm{O} / 16 \mathrm{O}_{2 \text { (sa) }}}{18 \mathrm{O} 16 \mathrm{O} / 16 \mathrm{O}_{2 \text { (air) }}}\right]-1\right\} 10^{3}$

Results of the $\delta 15 \mathrm{~N}$ of trapped $\mathrm{N}_{2}\left(\delta 15 \mathrm{~N}_{\mathrm{N}_{2} \text { ice }}\right)$ and $\delta 18 \mathrm{O}$ of trapped $\mathrm{O}_{2}\left(\delta 18 \mathrm{O}_{2}\right.$ ice $)$ are reported in Table 1. The $\delta 15 \mathrm{~N}_{\mathrm{N}_{2}}$ ice results are used to correct the $\delta 18 \mathrm{O}_{2}$ ice values for gravitational fractionation of air in the firn prior to occlusion [Craig et al., 1988; Schwander, 1989; Sowers et al., 1989] according to the following equation:

$\delta 18 \mathrm{O}_{\mathrm{atm}}=\delta 18 \mathrm{O}_{\mathrm{O}_{2} \text { ice }}-2\left(\delta 15 \mathrm{~N}_{\mathrm{N}_{2} \text { ice }}\right)$
Results are listed in Table 1.

We sampled the Vostok $3 \Gamma$ core roughly every 25 $\mathrm{m}$ starting at $140 \mathrm{~m}$ below the surface (mbs) and continuing down to $2058 \mathrm{mbs}$. Given an age of 160 $\mathrm{ka}$ for the bottom ( $2083 \mathrm{mbs}$ ) of the $3 \Gamma$ core [Lorius et al., 1985], our sampling frequency for the deep core corresponds roughly to one sample every 2,000 years. This value is comparable to the current turnover time of atmospheric $\mathrm{O}_{2}$ [Bender et al., 1985]. In addition to sampling every $25 \mathrm{~m}$, we performed high-resolution sampling during periods of major climate change. On the other hand, poor core quality limited our sampling to $50 \mathrm{~m}$ between 500- and 700-m depth.

We also analyzed 17 samples from the 114.8- to 171.1-m depth interval in the BH-1 short core (178 m) which was drilled during the 35 th Soviet Antarctic expedition in 1989-1990. These samples provided a high-resolution record covering the last 3 kyr.

Both the $3 \Gamma$ and the BH-1 short cores were drilled using a thermal drill. As a result, core quality is poor at shallow depths. There are two indications that the accuracy of our results for samples above $1000 \mathrm{mbs}$ may have been slightly compromised by this poor core quality. First, $\delta 18 \mathrm{O}_{\mathrm{atm}}$ in the Holocene samples of Vostok is significantly greater than the modern atmospheric value adopted as the reference and therefore defined to be $0 \%$. The mean $\delta 18 \mathrm{O}_{\mathrm{atm}}$ of samples with ages $<2.5 \mathrm{kyr}$ is $0.19 \pm 0.09 \%$ o $(1 \sigma, \mathrm{n}$ $=21$ ). Analyses of samples in this age range from the high-quality GISP II core, indicate that the $\delta 180$ of atmospheric $\mathrm{O}_{2}$ has been $0.1 \pm 0.1 \% \circ(1 \sigma, \mathrm{n}=32)$ during this interval (T. Sowers and $M$. Bender, unpublished data, 1993). Second, some adjacent samples indicate abrupt changes in $\delta 180$ which are geochemically unreasonable given the 2-kyr turnover time of atmospheric $\mathrm{O}_{2}$. Thus the uncertainty in $\delta 18 \mathrm{O}_{\mathrm{atm}}$ in the upper part of the Vostok core is greater than our precision; we assign a value of \pm $0.2 \%$. There is no reason to believe that there is any such error in samples below 1,000-m depth ( 60 $\mathrm{ka}$ ), where preservation is very good.

A plot of $\delta 18 \mathrm{O}_{\mathrm{atm}}$ versus depth in the Vostok cores was constructed by connecting average $\delta 18 \mathrm{O}_{\mathrm{atm}}$ values at each depth (Figure 2). The average standard deviation about the mean of all 95 depths is $\pm 0.05 \%$. We compare the $\delta D_{\text {ice }}$ record from Jouzel et al. [1987] with the $\delta 180_{\mathrm{atm}}$ record in Figure 2. In general, high $\delta 18 \mathrm{O}_{\mathrm{atm}}$ values are associated with low $\delta \mathrm{D}_{\mathrm{ice}}$ values which are generally thought to be indicative of colder periods.

In order to compare our $\delta 18 \mathrm{O}_{\mathrm{atm}}$ data with the $\delta 180_{\text {sw }}$ record in the time domain, we utilize the Lorius et al. [1985] ice chronology and the $\Delta$ age estimates from Barnola et al. [1991]. Today, in the Vostok region of Antarctica, air parcels are being occluded into bubbles between 95 and $105 \mathrm{mbs}$ [Barnola et al., 1987; Barnola et al., 1991]. The age of the ice at these two depths is 2,600 and 3,000 
TABLE 1. Results of Trapped Gas Analysis From the Vostok Ice Core

\begin{tabular}{|c|c|c|c|c|c|}
\hline Sample Depth, & Ice Age, ${ }^{a}$ & Gas Age, $\boldsymbol{b}$ & Trappe & Gases & $\begin{array}{c}\delta^{18} \mathrm{O} \text { of } \\
\text { Atmospheric }\end{array}$ \\
\hline mbs & & & $\delta^{15} \mathrm{~N} . \% 0$ & $\delta^{18} 0 . \% 0$ & \\
\hline $114.8 \mathrm{a}$ & 3.6 & 0.8 & 0.48 & 1.10 & 0.13 \\
\hline $114.8 \mathrm{~b}$ & & & 0.39 & 0.93 & 0.15 \\
\hline $116.3 a$ & 3.7 & 0.9 & 0.46 & 1.12 & 0.20 \\
\hline $116.3 b$ & & & 0.40 & 1.06 & 0.25 \\
\hline $120.3 a$ & 3.8 & 1.1 & 0.49 & 1.09 & 0.11 \\
\hline $120.3 b$ & & & 0.49 & 1.15 & 0.16 \\
\hline $125.2 \mathrm{a}$ & 4.0 & 1.3 & 0.43 & 1.07 & 0.20 \\
\hline $125.2 \mathrm{~b}$ & & & 0.45 & 1.05 & 0.16 \\
\hline $130.1 \mathrm{a}$ & 4.2 & 1.5 & 0.37 & 1.01 & 0.26 \\
\hline $130.1 b$ & & & 0.39 & 1.09 & 0.31 \\
\hline $135.3 \mathrm{a}$ & 4.4 & 1.7 & 0.50 & 1.11 & 0.10 \\
\hline $135.3 \mathrm{~b}$ & & & 0.45 & 1.27 & 0.37 \\
\hline $139.7 \mathrm{a}$ & 4.6 & 1.9 & 0.48 & 1.04 & 0.08 \\
\hline $139.7 \mathrm{~b}$ & & & 0.43 & 1.08 & 0.22 \\
\hline $139.8 \mathrm{a}$ & 4.6 & 1.9 & 0.39 & 1.11 & 0.33 \\
\hline $139.8 b$ & & & 0.38 & 1.11 & 0.35 \\
\hline $143.7 \mathrm{a}$ & 4.7 & 2.1 & 0.50 & 1.11 & 0.10 \\
\hline $143.7 \mathrm{~b}$ & & & 0.49 & 1.11 & 0.12 \\
\hline $149.6 \mathrm{a}$ & 5.0 & 2.3 & 0.43 & 1.02 & 0.15 \\
\hline $149.6 \mathrm{~b}$ & & & 0.47 & 1.08 & 0.15 \\
\hline 152.8 & 5.1 & 2.5 & 0.47 & 1.05 & 0.11 \\
\hline 156.9 & 5.3 & 2.6 & 0.51 & 1.14 & 0.12 \\
\hline $161.8 \mathrm{a}$ & 5.5 & 2.8 & 0.49 & 1.03 & 0.05 \\
\hline $161.8 \mathrm{~b}$ & & & 0.44 & 1.00 & 0.13 \\
\hline $165.1 \mathrm{a}$ & 5.6 & 3.0 & 0.49 & 1.05 & 0.07 \\
\hline $165.1 \mathrm{~b}$ & & & 0.49 & 1.06 & 0.08 \\
\hline $166.8 \mathrm{a}$ & 5.7 & 3.1 & 0.49 & 1.13 & 0.15 \\
\hline $166.8 \mathrm{~b}$ & & & 0.46 & 1.07 & 0.15 \\
\hline $169.7 \mathrm{a}$ & 5.8 & 3.2 & 0.48 & 1.04 & 0.07 \\
\hline $169.7 \mathrm{~b}$ & & & 0.63 & 1.29 & 0.04 \\
\hline $169.7 \mathrm{c}$ & & & 0.46 & 0.97 & 0.04 \\
\hline 174.6 & 5.9 & 3.3 & 0.47 & 1.00 & 0.06 \\
\hline $177.1 \mathrm{a}$ & 6.1 & 3.5 & 0.54 & 1.33 & 0.24 \\
\hline $177.1 \mathrm{~b}$ & & & 0.45 & 1.14 & 0.24 \\
\hline $184.3 \mathrm{a}$ & 6.4 & 3.8 & 0.40 & 1.04 & 0.25 \\
\hline $184.3 b$ & & & 0.39 & 1.24 & 0.46 \\
\hline $213.8 \mathrm{a}$ & 7.7 & 5.1 & 0.43 & 0.81 & -0.05 \\
\hline $213.8 b$ & & & 0.42 & 0.88 & 0.04 \\
\hline $269.5 a$ & 10.2 & 7.6 & 0.45 & 0.87 & -0.03 \\
\hline $269.5 b$ & & & 0.41 & 0.95 & 0.13 \\
\hline $294.5 a$ & 11.5 & 8.7 & 0.42 & 1.17 & 0.33 \\
\hline $294.5 b$ & & & 0.48 & 1.31 & 0.34 \\
\hline 303.6a & 11.9 & 9.1 & 0.46 & 1.42 & 0.50 \\
\hline $331.4 \mathrm{a}$ & 13.5 & 10.2 & 0.43 & 1.74 & 0.89 \\
\hline 331.4b & & & 0.43 & 1.85 & 1.00 \\
\hline $356.8 a$ & 15.1 & 11.5 & 0.37 & 1.95 & 1.21 \\
\hline
\end{tabular}


TABLE 1. (continued)

\begin{tabular}{|c|c|c|c|c|c|}
\hline \multirow{2}{*}{$\begin{array}{l}\text { Sample Depth, } \\
\text { mbs }\end{array}$} & \multirow{2}{*}{$\begin{array}{l}\text { Ice Age, }{ }^{a} \\
\text { ka }\end{array}$} & \multirow{2}{*}{$\begin{array}{c}\text { Gas Age, } b \\
\text { ka }\end{array}$} & \multicolumn{2}{|c|}{ Trapped Gases } & \multirow{2}{*}{$\begin{array}{c}\delta^{18} \mathrm{O} \text { of } \\
\text { Atmospheric } \\
\mathrm{O}_{2}, \% 0 \\
\end{array}$} \\
\hline & & & $\delta^{15} \mathrm{~N}, \%_{0}$ & $\delta^{18} \mathrm{O}, \%$ & \\
\hline $356.8 \mathrm{~b}$ & & & 0.39 & 2.11 & 1.33 \\
\hline $381.5 \mathrm{a}$ & 16.9 & 12.8 & 0.38 & 2.15 & 1.39 \\
\hline $381.5 b$ & & & 0.35 & 2.20 & 1.49 \\
\hline $409.0 \mathrm{a}$ & 19.0 & 14.1 & 0.38 & 2.05 & 1.29 \\
\hline $409.0 \mathrm{~b}$ & & & 0.38 & 2.10 & 1.35 \\
\hline $434.2 \mathrm{a}$ & 21.1 & 15.3 & 0.42 & 2.06 & 1.23 \\
\hline $434.2 b$ & & & 0.41 & 2.11 & 1.30 \\
\hline $443.7 a$ & 21.9 & 15.8 & 0.54 & 1.94 & 0.86 \\
\hline $443.7 \mathrm{~b}$ & & & 0.39 & 1.92 & 1.15 \\
\hline $483.7 \mathrm{a}$ & 25.2 & 19.1 & 0.48 & 2.06 & 1.10 \\
\hline $483.7 \mathrm{~b}$ & & & 0.41 & 1.93 & 1.11 \\
\hline $534.5 \mathrm{a}$ & 29.4 & 24.0 & 0.51 & 1.49 & 0.46 \\
\hline $534.5 b$ & & & 0.47 & 1.54 & 0.60 \\
\hline $585.5 \mathrm{a}$ & 33.4 & 28.2 & 0.41 & 1.69 & 0.87 \\
\hline $585.5 \mathrm{~b}$ & & & 0.39 & 1.72 & 0.95 \\
\hline 656.5 & 39.0 & 33.7 & 0.39 & 1.40 & 0.62 \\
\hline $694.5 a$ & 41.9 & 36.6 & 0.35 & 1.28 & 0.58 \\
\hline $694.5 b$ & & & 0.29 & 1.24 & 0.66 \\
\hline $759.8 a$ & 46.8 & 41.6 & 0.38 & 1.24 & 0.48 \\
\hline $759.8 \mathrm{~b}$ & & & 0.37 & 1.28 & 0.53 \\
\hline 788.5a & 49.0 & 44.0 & 0.48 & 1.30 & 0.35 \\
\hline $788.5 b$ & & & 0.50 & 1.38 & 0.39 \\
\hline $806.2 a$ & 50.3 & 45.6 & 0.38 & 1.23 & 0.48 \\
\hline $806.2 b$ & & & 0.38 & 1.32 & 0.56 \\
\hline $834.2 \mathrm{a}$ & 52.4 & 47.8 & 0.32 & 1.22 & 0.58 \\
\hline $834.2 b$ & & & 0.35 & 1.32 & 0.63 \\
\hline $857.6 a$ & 54.2 & 49.6 & 0.39 & 1.23 & 0.45 \\
\hline 857.6b & & & 0.32 & 1.26 & 0.61 \\
\hline $885.6 \mathrm{a}$ & 56.3 & 51.9 & 0.31 & 1.34 & 0.71 \\
\hline $885.6 b$ & & & 0.31 & 1.33 & 0.71 \\
\hline 908.2 & 58.1 & 53.7 & 0.35 & 1.58 & 0.87 \\
\hline 934.4a & 60.3 & 55.6 & 0.33 & 1.62 & 0.97 \\
\hline 934.4b & & & 0.33 & 1.76 & 1.09 \\
\hline 937.3 & 60.6 & 55.8 & 0.40 & 1.70 & 0.89 \\
\hline 957.4a & 62.3 & 57.3 & 0.33 & 1.57 & 0.90 \\
\hline 957.4b & & & 0.34 & 1.61 & 0.93 \\
\hline $982.3 a$ & 64.5 & 59.0 & 0.41 & 1.61 & 0.79 \\
\hline $982.3 b$ & & & 0.30 & 1.62 & 1.02 \\
\hline $1003.4 \mathrm{a}$ & 66.3 & 60.7 & 0.38 & 1.67 & 0.92 \\
\hline $1003.4 b$ & & & 0.37 & 1.73 & 1.00 \\
\hline 1017.2a & 67.5 & 61.9 & 0.38 & 1.71 & 0.96 \\
\hline $1017.2 \mathrm{~b}$ & & & 0.33 & 1.73 & 1.08 \\
\hline $1037.7 \mathbf{a}$ & 69.2 & 63.8 & 0.33 & 1.37 & 0.72 \\
\hline $1037.7 \mathrm{~b}$ & & & 0.39 & 1.67 & 0.89 \\
\hline $1060.5 a$ & 71.2 & 65.9 & 0.35 & 1.59 & 0.88 \\
\hline $1060.5 b$ & & & 0.32 & 1.67 & 1.02 \\
\hline $1082.0 \mathrm{a}$ & 72.9 & 67.9 & 0.36 & 1.39 & 0.68 \\
\hline
\end{tabular}


TABLE 1. (continued)

\begin{tabular}{|c|c|c|c|c|c|}
\hline $\begin{array}{c}\text { Sample Depth, } \\
\text { mbs }\end{array}$ & $\begin{array}{c}\text { Ice Age, }{ }^{a} \\
\text { ka }\end{array}$ & $\begin{array}{c}\text { Gas Age }{ }^{b} \\
\text { ka }\end{array}$ & $\begin{array}{r}\text { Trappe } \\
\delta^{15} \mathrm{~N}, \% 0 \\
\end{array}$ & $\frac{\text { Gases }}{\delta^{18} 0, \% 0}$ & $\begin{array}{c}\delta^{18} \mathrm{O} \text { of } \\
\text { Atmospheric } \\
\mathrm{O}_{2, \% 0}\end{array}$ \\
\hline $1082.0 \mathrm{~b}$ & & & 0.34 & 1.42 & 0.74 \\
\hline $1108.4 a$ & 75.1 & 70.4 & 0.37 & 1.28 & 0.53 \\
\hline $1108.4 b$ & & & 0.34 & 1.35 & 0.67 \\
\hline 1134.6 & 77.2 & 72.7 & 0.33 & 1.26 & 0.60 \\
\hline $1157.7 \mathrm{a}$ & 79.0 & 74.7 & 0.37 & 1.00 & 0.26 \\
\hline $1157.7 b$ & & & 0.31 & 1.10 & 0.48 \\
\hline $1162.5 a$ & 79.4 & 75.2 & 0.37 & 0.89 & 0.15 \\
\hline $1162.5 b$ & & & 0.33 & 0.95 & 0.30 \\
\hline $1181.3 a$ & 80.8 & 76.9 & 0.36 & 0.73 & 0.01 \\
\hline $1181.3 b$ & & & 0.32 & 0.79 & 0.15 \\
\hline $1205.5 a$ & 82.7 & 79.0 & 0.32 & 0.74 & 0.11 \\
\hline $1205.5 b$ & & & 0.28 & 0.96 & 0.41 \\
\hline $1233.8 \mathrm{a}$ & 84.9 & 81.3 & 0.29 & 0.87 & 0.29 \\
\hline $1233.8 b$ & & & 0.33 & 1.03 & 0.37 \\
\hline $1265.2 \mathrm{a}$ & 87.3 & 83.3 & 0.37 & 1.41 & 0.67 \\
\hline $1265.2 \mathrm{~b}$ & & & 0.31 & 1.37 & 0.75 \\
\hline 1290.4 & 89.2 & 85.0 & 0.30 & 1.29 & 0.70 \\
\hline $1307.7 \mathrm{a}$ & 90.6 & 86.2 & 0.35 & 1.19 & 0.49 \\
\hline $1307.7 \mathrm{~b}$ & & & 0.29 & 1.13 & 0.56 \\
\hline $1309.5 \mathrm{a}$ & 90.7 & 86.3 & 0.39 & 1.27 & 0.50 \\
\hline $1309.5 b$ & & & 0.31 & 1.15 & 0.52 \\
\hline $1333.3 \mathrm{a}$ & 92.6 & 88.4 & 0.27 & 1.12 & 0.58 \\
\hline $1333.3 b$ & & & 0.29 & 1.28 & 0.70 \\
\hline $1363.7 \mathrm{a}$ & 95.0 & 90.9 & 0.34 & 1.38 & 0.70 \\
\hline $1363.7 \mathrm{~b}$ & & & 0.36 & 1.56 & 0.84 \\
\hline $1391.2 \mathrm{a}$ & 97.2 & 93.2 & 0.32 & 1.27 & 0.63 \\
\hline $1391.2 b$ & & & 0.32 & 1.33 & 0.69 \\
\hline $1419.7 a$ & 99.5 & 95.8 & 0.37 & 1.16 & 0.41 \\
\hline $1419.7 \mathrm{~b}$ & & & 0.36 & 1.17 & 0.45 \\
\hline $1443.0 \mathrm{a}$ & 101.5 & 97.9 & 0.33 & 0.89 & 0.23 \\
\hline $1443.0 \mathrm{~b}$ & & & 0.32 & 0.94 & 0.30 \\
\hline $1467.7 \mathrm{a}$ & 103.6 & 100.1 & 0.29 & 0.69 & 0.11 \\
\hline $1467.7 \mathrm{~b}$ & & & 0.27 & 0.68 & 0.14 \\
\hline $1494.3 \mathrm{a}$ & 106.1 & 102.3 & 0.28 & 0.77 & 0.21 \\
\hline $1494.3 b$ & & & 0.29 & 0.81 & 0.22 \\
\hline $1505.0 \mathrm{a}$ & 107.1 & 103.2 & 0.41 & 0.80 & -0.03 \\
\hline $1505.0 \mathrm{~b}$ & & & 0.35 & 0.75 & 0.05 \\
\hline 1514.3 & 108.0 & 104.0 & 0.41 & 0.97 & 0.16 \\
\hline $1566.2 \mathrm{a}$ & 113.0 & 108.3 & 0.40 & 1.58 & 0.77 \\
\hline $1566.2 b$ & & & 0.41 & 1.63 & 0.80 \\
\hline $1592.0 \mathrm{a}$ & 115.3 & 110.5 & 0.42 & 1.71 & 0.88 \\
\hline $1592.0 \mathrm{~b}$ & & & 0.39 & 1.76 & 0.97 \\
\hline $1636.3 a$ & 119.0 & 115.1 & 0.38 & 1.67 & 0.90 \\
\hline $1636.3 b$ & & & 0.36 & 1.68 & 0.96 \\
\hline $1656.1 \mathrm{a}$ & 120.6 & 117.2 & 0.58 & 1.60 & 0.44 \\
\hline $1656.1 \mathrm{~b}$ & & & 0.40 & 1.53 & 0.73 \\
\hline $1683.3 \mathrm{a}$ & 122.6 & 119.6 & 0.38 & 1.22 & 0.47 \\
\hline
\end{tabular}


TABLE 1. (continued)

\begin{tabular}{|c|c|c|c|c|c|}
\hline \multirow{2}{*}{ Sample Depth, } & \multirow{2}{*}{$\begin{array}{l}\text { Ice Age, }{ }^{a} \\
\text { ka }\end{array}$} & \multirow{2}{*}{$\underset{\mathrm{ka}}{\underset{\mathrm{kas}}{\mathrm{G}} \mathrm{Age}, \boldsymbol{b}}$} & \multirow{2}{*}{\multicolumn{2}{|c|}{$\frac{\text { Trapped Gases }}{8^{15} \mathrm{~N}}$}} & \multirow{2}{*}{$\begin{array}{c}\delta^{18} \mathrm{O} \text { of } \\
\text { Atmospheric } \\
\mathrm{O}_{2}, \%_{0}\end{array}$} \\
\hline & & & & & \\
\hline $1683.3 b$ & & & 0.38 & 1.26 & 0.50 \\
\hline $1693.1 \mathrm{a}$ & 123.3 & 120.4 & 0.50 & 1.14 & 0.13 \\
\hline $1693.1 \mathrm{~b}$ & & & 0.50 & 1.14 & 0.14 \\
\hline $1716.7 \mathrm{a}$ & 125.0 & 122.3 & 0.46 & 0.86 & -0.05 \\
\hline $1716.7 b$ & & & 0.42 & 0.89 & 0.04 \\
\hline 1732.7 & 126.1 & 123.5 & 0.43 & 0.88 & 0.01 \\
\hline $1757.0 \mathrm{a}$ & 127.8 & 125.2 & 0.43 & 0.78 & -0.08 \\
\hline $1757.0 \mathrm{~b}$ & & & 0.35 & 0.68 & -0.03 \\
\hline $1784.3 a$ & 129.7 & 127.3 & 0.40 & 0.61 & -0.18 \\
\hline $1784.3 b$ & & & 0.41 & 0.71 & -0.11 \\
\hline $1823.5 \mathrm{a}$ & 132.5 & 130.3 & 0.41 & 0.76 & -0.05 \\
\hline $1823.5 \mathrm{~b}$ & & & 0.40 & 0.80 & 0.00 \\
\hline $1831.9 \mathrm{a}$ & 133.2 & 131.0 & 0.56 & 1.03 & -0.08 \\
\hline $1831.9 \mathrm{~b}$ & & & 0.51 & 1.06 & 0.05 \\
\hline $1845.2 \mathrm{a}$ & 134.1 & 132.1 & 0.43 & 1.19 & 0.34 \\
\hline $1845.2 \mathrm{~b}$ & & & 0.40 & 1.20 & 0.41 \\
\hline $1858.0 \mathrm{a}$ & 135.1 & 133.0 & 0.50 & 1.42 & 0.43 \\
\hline $1858.0 \mathrm{~b}$ & & & 0.44 & 1.39 & 0.51 \\
\hline 1868.5 & 135.9 & 133.7 & 0.48 & 1.81 & 0.85 \\
\hline $1882.3 a$ & 137.0 & 134.6 & 0.44 & 2.03 & 1.16 \\
\hline $1882.3 \mathrm{~b}$ & & & 0.39 & 2.02 & 1.23 \\
\hline $1883.4 \mathrm{a}$ & 137.1 & 134.7 & 0.47 & 2.03 & 1.08 \\
\hline $1883.4 \mathrm{~b}$ & & & 0.49 & 2.10 & 1.12 \\
\hline $1907.6 a$ & 139.2 & 136.4 & 0.47 & 2.24 & 1.30 \\
\hline $1907.6 \mathrm{~b}$ & & & 0.43 & 2.19 & 1.33 \\
\hline $1907.6 c$ & & & 0.43 & 2.22 & 1.36 \\
\hline $1934.5 \mathrm{a}$ & 141.9 & 138.3 & 0.41 & 2.22 & 1.40 \\
\hline 1934.5b & & & 0.40 & 2.26 & 1.45 \\
\hline $1954.6 \mathrm{a}$ & 144.2 & 139.8 & 0.34 & 2.04 & 1.37 \\
\hline $1954.6 \mathrm{~b}$ & & & 0.38 & 2.21 & 1.46 \\
\hline $1955.8 \mathrm{a}$ & 144.3 & 139.9 & 0.39 & 2.08 & 1.31 \\
\hline $1955.8 \mathrm{~b}$ & & & 0.34 & 2.01 & 1.32 \\
\hline $1965.5 \mathrm{a}$ & 145.5 & 140.7 & 0.35 & 2.01 & 1.31 \\
\hline $1965.5 b$ & & & 0.33 & 2.08 & 1.41 \\
\hline $1982.3 \mathrm{a}$ & 147.9 & 142.4 & 0.36 & 1.94 & 1.22 \\
\hline $1982.3 \mathrm{~b}$ & & & 0.35 & 1.94 & 1.24 \\
\hline $1990.8 \mathrm{a}$ & 149.2 & 143.4 & 0.47 & 1.98 & 1.04 \\
\hline $1990.8 b$ & & & 0.44 & 1.97 & 1.09 \\
\hline 2016.4a & 153.4 & 147.6 & 0.41 & 1.90 & 1.09 \\
\hline 2016.4b & & & 0.29 & 1.71 & 1.14 \\
\hline 2058.8a & 160.5 & 154.4 & 0.45 & 1.64 & 0.74 \\
\hline 2058.8b & & & 0.43 & 1.71 & 0.84 \\
\hline
\end{tabular}

Columns 4 and 5 are the isotopic composition of trapped $\mathrm{N}_{2}$ and $\mathrm{O}_{2}$, respectively, relative to the present-day atmosphere. The last column is $\delta 18 \mathrm{O}_{\mathrm{atm}}$, the paleoatmospheric $\delta^{18} \mathrm{O}$ of $\mathrm{O}_{2}$ after correction for gravitational fractionation (equation (2)). Note that mbs indicates meters below the surface.

a Data are from Lorius et al. [1985].

$b$ Data are from Barnola et al. [1991]. 


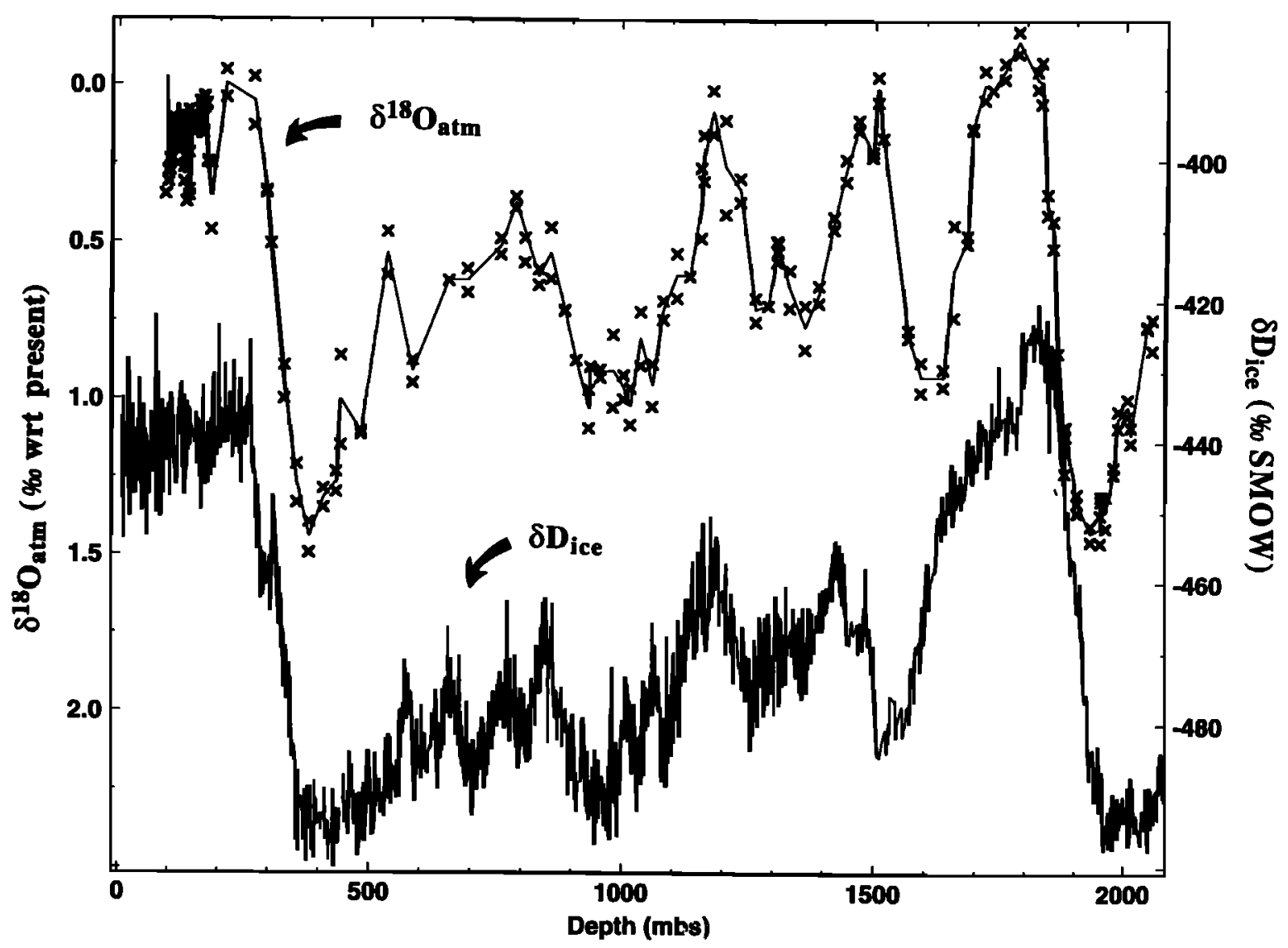

Fig. 2. Isotopic composition of paleoatmospheric $\mathrm{O}_{2}\left(\delta^{18 \mathrm{O}_{\mathrm{atm}}}\right)$ based on the isotopic composition of trapped $\mathrm{O}_{2}$ in the Vostok ice core (top). Results are reported relative to the present-day atmosphere. The results from each analysis are plotted (with crosses) along with a line joining all the average values at each depth. Also plotted is the $\delta D_{\text {ice }}$ record from Jouzel et al. [1987] (bottom). Low $\delta 180_{a t m}$ values are generally associated with high $\delta D_{\text {ice }}$ values.

years B.P. respectively [Jouzel et al., 1987], which implies that the bubbles of air which have recently formed near Vostok are between 2,600 and 3,000 years younger than the surrounding ice. For this study, $\Delta$ age is taken as the age of the firn at midpoint of the close off depth interval.

Our $\delta 18 \mathrm{O}_{\mathrm{atm}}$ data are plotted in Figure 3 versus age according to the Vostok gas chronology of Barnola et al. [1991]. We also plot the $\delta 18 \mathrm{O}_{\mathrm{sw}}$ record, discussed previously, versus age according to the SPECMAP chronology. The range of $\delta 180$ values for the two records is similar, $1.3 \%$ and $1.6 \% \circ$ for $\delta 18 \mathrm{O}_{\mathrm{sw}}$ and $\delta 18 \mathrm{O}_{\mathrm{atm}}$, respectively. The general forms of the two records are strikingly similar. The divergence between the two records for ages $>110$ ka can easily be accounted for given uncertainties in the timescales.

Geochemical Controls on the $818 O$ of Atmospheric $\mathrm{O}_{2}$ : The Morita-Dole Effect

Morita [1935], Dole [1935], Dole et al. [1954], and Kroopnick and Craig [1972] have shown that the $\delta 18 \mathrm{O}$ of atmospheric $\mathrm{O}_{2}$ today is $+23.5 \%$ o relative to standard mean ocean water. This $23.5 \%$ o difference between atmospheric $\mathrm{O}_{2}$ and seawater is referred to as the Morita-Dole effect (hereinafter referred to as the M-D effect). The M-D effect results from oxygen isotope fractionation associated with the photosynthetic production of $\mathrm{O}_{2}$ both on land and in the ocean, and from fractionation associated with the consumption of $\mathrm{O}_{2}$ during aerobic respiration.

As noted by Sowers et al. [1991], there are at least four factors which may have caused $\delta 18 \mathrm{O}_{\mathrm{atm}}$ in the past to be different from today's value. First, changes in $\delta 18 \mathrm{O}_{\mathrm{sw}}$ result from changes in continental ice volume and directly impact the $\delta 18 \mathrm{O}$ of photosynthetic $\mathrm{O}_{2}$ produced in the ocean. Changes in $\delta 18 \mathrm{O}_{\mathrm{sw}}$ also affect the $\delta 18 \mathrm{O}$ of water evaporating from the ocean, the $\delta 180$ of precipitation on the continents, and ultimately, the $\delta 180$ of photosynthetic $\mathrm{O}_{2}$ produced on the continents. Second, changes in the hydrologic cycle on glacial/interglacial timescales influence the $\delta 180$ of leaf water and thereby the $\delta 18 \mathrm{O}$ of photosynthetic $\mathrm{O}_{2}$ 


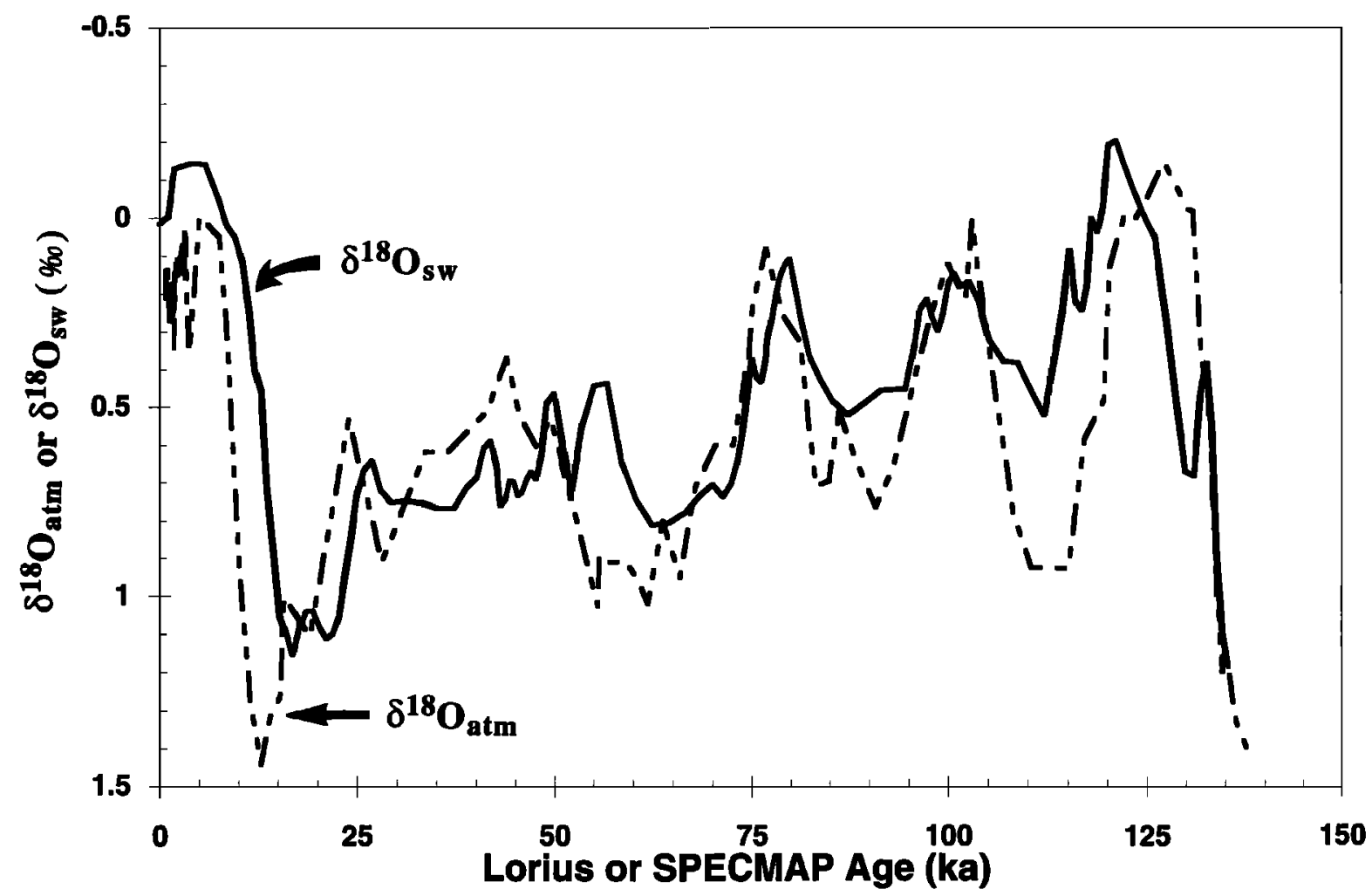

Fig. 3. Records of the $\delta 18 \mathrm{O}_{\mathrm{atm}}$ (dashed line) and $\delta 18 \mathrm{O}_{\mathrm{sw}}$ (solid line) from V19-30 plotted on the Bamola et al. [1991] and SPECMAP [Martinson et al., 1987] timescales, respectively. The $\delta 18 \mathrm{O}_{\mathrm{atm}}$ record is reported relative to the present-day atmosphere. The $\delta 18 \mathrm{O}_{\mathrm{sw}}$ record has been

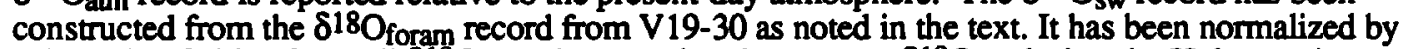
subtracting 3.46\% from all $\delta 18 \mathrm{O}_{\text {sw }}$ values, so that the average $818 \mathrm{O}_{\text {sw }}$ during the Holocene is $0 \%$. Some of the discrepancies between the two records may be due to chronological inconsistencies between the two timescales. Between warm periods, the $\delta 18 \mathrm{O}_{\mathrm{atm}}$ record shows much larger variations than the $\delta 18 \mathrm{O}_{\mathrm{sw}}$ record, suggesting that $\delta 18 \mathrm{O}_{\mathrm{atm}}$ may not be an ideal proxy for $\delta 180_{s w}$, especially during these periods.

produced on the continents. Third, ecological changes over glacial/interglacial timescales cause the giobal average of the respiratory isotope effect to change. One can imagine such changes resulting either from changes in the make-up of the marine and continental biospheres or from changes in the isotope effects on the species level. Finally, changes in the ratio of continental to marine gross primary productivity may have had a large effect on $\delta 18 \mathrm{O}_{\mathrm{atm}}$, because the $\delta 18 \mathrm{O}$ of leaf water is generally heavier than that of seawater. For reference, the residence time of atmospheric $\mathrm{O}_{2}$ today, with respect to photosynthesis and respiration, is estimated to be between 2,000 and 3,000 years [Bender et al., 1985].

We can gain some insight into the factors which have influenced $\delta 18 \mathrm{O}_{\mathrm{atm}}$ by examining Figure 3 in more detail. If we assume, for the moment, that some of the offset between the $\delta 18 \mathrm{O}_{\mathrm{sw}}$ and $\delta 18 \mathrm{O}_{\mathrm{atm}}$ is the result of chronological inconsistencies, then the high degree of covariation between the two records implies that the major factor influencing $\delta 18 \mathrm{O}_{\mathrm{atm}}$ is changes in $\delta 18 \mathrm{O}_{\mathrm{sw}}$. As we mentioned previously, the range of $\delta 18 \mathrm{O}_{\mathrm{atm}}$ values is similar to the $\delta 18 \mathrm{O}_{\mathrm{sw}}$ values over the last $150 \mathrm{kyr}$. This result suggests that the biologic and hydrologic factors which influence $\delta 18 \mathrm{O}_{\mathrm{atm}}$ have remained close to their present-day values. For example, a 30\% change in the ratio of marine to terrestrial productivity would produce a change of about $0.5 \% o$ in $\delta 18 \mathrm{O}_{\mathrm{atm}}$ relative to $\delta 18 \mathrm{O}_{\mathrm{sw}}$. The only time when a change of this magnitude is suggested by the data is during marine isotope stage $5 \mathrm{~d}(110 \mathrm{ka})$. We cannot rule out the possibility that there were substantial changes in the biologic and hydrologic cycles which had no net effect on $\delta 18 \mathrm{O}_{\mathrm{atm}}$, but we consider it unlikely given the similar nature of the two curves in Figure 3.

From the similarity of the two curves in Figure 3 
we tentatively conclude that (1) the major factor influencing $\delta 18 \mathrm{O}_{\mathrm{atm}}$ appears to be $\delta 18 \mathrm{O}_{\mathrm{sw}}$, (2) there are periods when the M-D effect was substantially different than it is today, and (3) the degree to which the first two conclusions may be considered valid depends on how well we can correlate the Vostok and SPECMAP chronologies.

We will now turn our attention to the development of the gas age versus depth relation for Vostok. As mentioned previously, we derive this relation by correlating our measured $\delta 18 \mathrm{O}_{\mathrm{atm}}$ record with the $\delta 18 \mathrm{O}_{\text {sw }}$ record from V19-30 (Figure 3) using the inverse correlation method developed by Martinson et al. [1982]. We then test the fidelity of this common framework by comparing temperature records from the two media.

\section{CONSTRUCTION OF A "COMMON TEMPORAL FRAMEWORK"}

\section{Establishing a Gas Age-Depth Curve for Vostok}

Based on the good agreement between the $\delta 18 \mathrm{O}_{\mathrm{atm}}{ }^{-}$age and $\delta 18 \mathrm{O}_{\mathrm{sw}}$ - age records, we conclude that the major factor causing changes in $\delta 18 \mathrm{O}_{\mathrm{atm}}$ is variability in $\delta 18 \mathrm{O}_{\mathrm{sw}}$. We now assume that the M-D effect has been constant at the modern value of $+23.5 \%$ o during the period of our study and derive a curve of gas age versus depth for the Vostok ice core by correlating the Vostok curve of $\delta 18 \mathrm{O}_{\mathrm{atm}}$ versus depth into the V19-30 curve of $\delta 18 \mathrm{O}_{\text {sw }}$ versus age [Martinson et al., 1982; Martinson et al., 1987]. Before proceeding, we note that there were times when the M-D effect clearly deviated from the modern value. Thus the correlation that we derive is based on an assumption which is not completely correct and will undoubtedly need to be further refined.

The first step in deriving our age-depth curve for Vostok was to choose the deepest and shallowest depths we wished to correlate and assign ages to these two depths. As an upper bound, we choose our shallowest sample from $114.8 \mathrm{mbs}$. The ice age at $114.8 \mathrm{mbs}$ is $3.6 \mathrm{ka}$ [Lorius et al., 1985]; the age of the trapped air parcels at $114.8 \mathrm{mbs}$, calculated using the $\Delta$ age values of Barnola et al. [1991] (2.8 $\mathrm{kyr})$, is then $0.8 \mathrm{ka}(3.6 \mathrm{ka}-2.8 \mathrm{kyr})$. Because the turnover time of atmospheric $\mathrm{O}_{2}$ is about $2 \mathrm{kyr}$, the $\delta 18 \mathrm{O}_{\mathrm{atm}}$ of trapped gas dated to be $0.8 \mathrm{ka}$ reflects the $\delta 180$ of seawater at $2.8 \mathrm{ka}$ [Sowers et al., 1991].

We choose the depth of $1934.5 \mathrm{mbs}$ as the bottom of our correlation interval. The $\delta 18 \mathrm{O}_{\mathrm{atm}}$ reaches a maximum at this depth which corresponds to the $\delta 18 \mathrm{O}_{\mathrm{sw}}$ maximum, dated at $135 \mathrm{ka}$ in the SPECMAP chronology. This period corresponds to the glacial maximum preceding the penultimate deglaciation.

After tying the end-points of the two records, we applied a 1.0 -cycle/kyr filter to the $\delta 18 \mathrm{O}_{\mathrm{atm}}$ record and correlated the two records using the protocol developed by Martinson et al. [1982]. The correlation involves the construction of a mapping function (in our case a correlated gas age-depth curve) for the Vostok ice core. The mapping function consists of a sum of sinusoids (of increasing order) which have amplitudes chosen to maximize the amount of shared variance between the two $\delta 180$ records. The number of sinusoids added to the mapping function determines the resolution of the correlation. In our case, we stopped the correlation at a resolution of $\sim 17 \mathrm{kyr}$ ( 8 sinusoids). We chose to correlate the two records at this modest level of resolution because the characteristic response time for an ice sheet which has been subjected to changes in accumulation rate is approximately $17 \mathrm{kyr}$ [Imbrie et al., 1984]. The correlation coefficient between the correlated records was 0.88 ( $77 \%$ shared variance between the correlated records).

By correlating the $\delta 18 \mathrm{O}_{\mathrm{atm}}$ versus depth curve from Vostok into the $\delta 18 \mathrm{O}_{\mathrm{sw}}$ versus age record, we infer a gas age-depth relationship for the Vostok ice core. The implied age of the trapped gas sample, which we define as the correlation age, is equal to the gas age plus the atmospheric $\mathrm{O}_{2}$ turnover time, 2 kyr. Global productivity and hence the atmospheric $\mathrm{O}_{2}$ turnover time undoubtedly varied during glacialinterglacial cycles. Estimates vary widely but are generally within $25 \%$ of present-day values [Lyle, 1988; Meyer, 1988; Mix, 1989]. Changes of this magnitude would introduce an error of $\pm 0.5 \mathrm{kyr}$ to our gas ages. In Figure 4, we plot $\delta 18 \mathrm{O}_{\mathrm{atm}}$ versus the Vostok correlation age and $\delta 18 \mathrm{O}_{\mathrm{sw}}$ versus the SPECMAP age. This figure shows that one can derive a correlation age-depth curve for Vostok in which $\delta 18 \mathrm{O}_{\mathrm{atm}}$ and $\delta 18 \mathrm{O}_{\mathrm{sw}}$ track each other very well.

Figure 4 also shows that $\delta 18 \mathrm{O}_{\text {atm }}$ does not follow $\delta 18 \mathrm{O}_{\mathrm{sw}}$ exactly and that the M-D effect must have varied during the last $135 \mathrm{kyr}$. A detailed discussion of the variable M-D effect will be presented in a forthcoming paper. The range of variability in the M-D effect $(0.9 \%$ ) is about $75 \%$ as large as the range of $\delta 18 \mathrm{O}_{\mathrm{sw}}(1.3 \% o)$, and it may clearly impart significant errors to our Vostok age-depth curve, which is derived simply by assuming that the M-D effect has been constant. It is for this reason that we consider $\delta 180$ to be an equivocal correlation tool [Sowers et al., 1991].

\section{Establishing an Ice Age-Depth Curve for Vostok}

In the previous section we derived a gas age-depth relation by correlating the $\delta 18 \mathrm{O}_{\text {atm }}$ record from Vostok into the SPECMAP $\delta 18 \mathrm{O}_{\mathrm{sw}}$ record. In order to compare the isotopic and chemical composition of the paleoprecipitation at Vostok with the marine climate records, we need to calculate an ice age-depth curve for this core. Put another way, we need to 


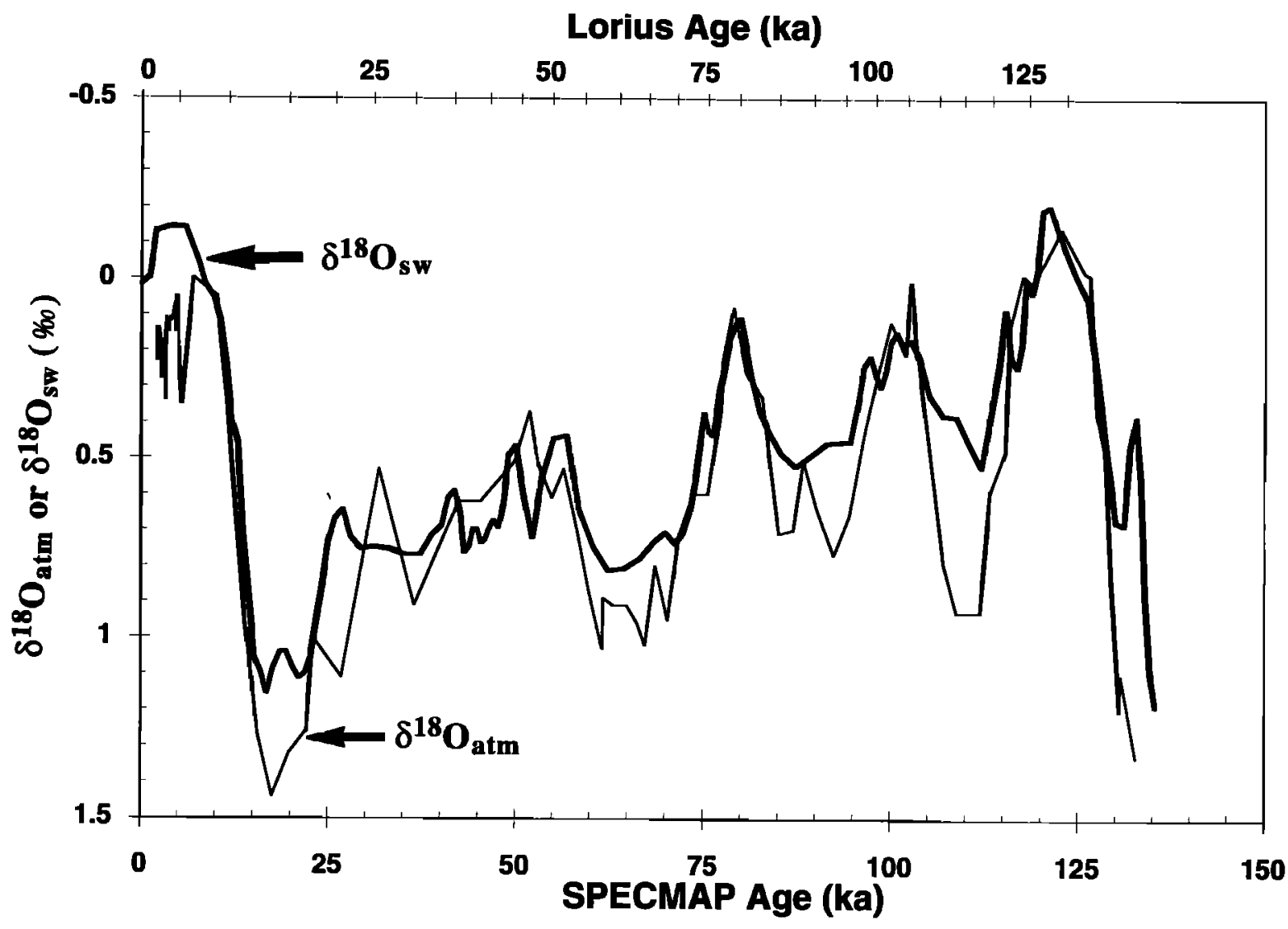

Fig. 4. Records of the $\delta 18 \mathrm{O}_{\mathrm{atm}}$ (thin line) and $\delta 18 \mathrm{O}_{\mathrm{sw}}$ (thick line) plotted on the SPECMAP [Martinson et al., 1987] timescale. The $\delta 180_{a t m}$ record has been correlated into the SPECMAP chronology using the inverse correlation method of Martinson et al. [1982]. We have purposely not tried to correlate the detailed features which are shorter than about $5 \mathrm{kyr}$. We believe the larger $\delta 18 \mathrm{O}_{\mathrm{atm}}$ variations are the result of changes in 180 fractionation which are most likely associated with the terrestrial biosphere. The Lorius et al. [1985] timescale is plotted on the upper axis for comparison. The $\delta 18 \mathrm{O}_{\mathrm{sw}}$ record is identical to that plotted in Figure 3.

account for the fact that the air parcels were trapped at least $100 \mathrm{~m}$ below the surface of the ice sheet and are thus younger than the surrounding ice. We refer to this age difference as the ice age-gas age difference ( $\Delta$ age). We have utilized a densification model [Herron and Langway, 1980], the record of the paleoaccumulation rate from our correlated gas agedepth curve, and an estimate of the thinning function [Ritz, 1992] to calculate a record of the paleo-closeoff depth and $\Delta$ age all along the core. Results of these calculations suggest that paleo-close-off depths varied between 100 and $125 \mathrm{~m}$ below the surface with corresponding $\Delta$ age values ranging from 2.9 to $7.0 \mathrm{kyr}$, respectively [Sowers et al., 1992]. Deeper close-off depths and larger values of $\Delta$ age occur during glacial periods when the temperature and accumulation rate were low. The appendix contains a detailed explanation of these factors and the associated errors. The resulting ice ages for each of our sample depths are listed in Table 2.

\section{IMPLICATIONS FOR CLIMATE LEADS AND LAGS}

Sowers et al. [1991] compared the depths at which the $\delta 180$ of $\mathrm{O}_{2}$ and $p \mathrm{CO}_{2}$ began to change at the beginning of the penultimate termination. They found that $\delta 180$ of $\mathrm{O}_{2}$ began to fall approximately 6 kyr before $p \mathrm{CO}_{2}$ began to rise. They concluded that the $p \mathrm{CO}_{2}$ rise led the $\delta 18 \mathrm{O}_{\mathrm{sw}}$ decrease by $4 \pm 1.7$ kyr (the response time of the $\delta 18 \mathrm{O}$ of atmospheric $\mathrm{O}_{2}$ to a change in $\delta 180$ of seawater is about $2 \mathrm{kyr}$ ). The age-depth curve of Pichon et al. [1992] supports this conclusion, as it puts the start of the $p \mathrm{CO}_{2}$ rise (and 
TABLE 2. Vostok Ice Core Correlation Ages

\begin{tabular}{|c|c|c|c|c|}
\hline \multirow{2}{*}{$\begin{array}{c}\text { Sample Depth, } \\
\text { mbs }\end{array}$} & \multirow{2}{*}{$\begin{array}{c}\text { Gas Age, } \\
\mathrm{ka}\end{array}$} & \multicolumn{2}{|c|}{ Ice Age, ka } & \multirow{2}{*}{$\begin{array}{l}\text { Correlated Ice Age } \\
\text { Lorius Ice Age, ka }\end{array}$} \\
\hline & & Correlated & Lorius ${ }^{\mathrm{a}}$ & \\
\hline 114.8 & 0.8 & 3.9 & 3.6 & 0.3 \\
\hline 116.3 & 0.9 & 4.0 & 3.6 & 0.4 \\
\hline 120.3 & 1.1 & 4.1 & 3.8 & 0.3 \\
\hline 125.2 & 1.3 & 4.3 & 4.0 & 0.3 \\
\hline 130.1 & 1.5 & 4.5 & 4.2 & 0.3 \\
\hline 135.3 & 1.7 & 4.8 & 4.4 & 0.4 \\
\hline 139.7 & 1.9 & 4.9 & 4.6 & 0.3 \\
\hline 139.8 & 1.9 & 4.9 & 4.6 & 0.3 \\
\hline 143.7 & 2.0 & 5.1 & 4.7 & 0.4 \\
\hline 149.6 & 2.3 & 5.3 & 5.0 & 0.3 \\
\hline 152.8 & 2.4 & 5.5 & 5.1 & 0.4 \\
\hline 156.9 & 2.6 & 5.6 & 5.3 & 0.3 \\
\hline 161.8 & 2.8 & 5.8 & 5.5 & 0.3 \\
\hline 165.1 & 2.9 & 6.0 & 5.6 & 0.4 \\
\hline 166.8 & 3.0 & 6.0 & 5.7 & 0.3 \\
\hline 169.7 & 3.1 & 6.1 & 5.8 & 0.3 \\
\hline 174.6 & 3.3 & 6.4 & 5.9 & 0.5 \\
\hline 177.1 & 3.4 & 6.5 & 6.1 & 0.4 \\
\hline 184.3 & 3.7 & 6.8 & 6.4 & 0.4 \\
\hline 213.8 & 5.0 & 8.1 & 7.7 & 0.4 \\
\hline 269.5 & 8.0 & 11.7 & 10.2 & 1.5 \\
\hline 294.5 & 9.5 & 14.0 & 11.5 & 2.5 \\
\hline 303.6 & 10.1 & 14.8 & 11.9 & 2.9 \\
\hline 331.4 & 11.9 & 17.4 & 13.5 & 3.9 \\
\hline 356.8 & 13.7 & 20.4 & 15.1 & 5.3 \\
\hline 381.5 & 15.6 & 23.9 & 16.9 & 7.0 \\
\hline 409.0 & 17.9 & 25.8 & 19.0 & 6.8 \\
\hline 434.2 & 20.2 & 27.8 & 21.1 & 6.7 \\
\hline 443.7 & 21.0 & 28.7 & 21.9 & 6.8 \\
\hline 483.7 & 24.9 & 32.0 & 25.2 & 6.8 \\
\hline 534.5 & 29.8 & 36.3 & 29.4 & 6.9 \\
\hline 585.5 & 34.5 & 40.2 & 33.4 & 6.8 \\
\hline 656.5 & 40.4 & 45.7 & 39.0 & 6.7 \\
\hline 694.5 & 43.3 & 48.3 & 41.9 & 6.4 \\
\hline 759.8 & 47.9 & 52.5 & 46.8 & 5.7 \\
\hline 788.5 & 49.9 & 54.3 & 49.0 & 5.3 \\
\hline 806.2 & 51.1 & 55.8 & 50.3 & 5.5 \\
\hline 834.2 & 52.9 & 57.3 & 52.4 & 4.9 \\
\hline 857.6 & 54.5 & 58.5 & 54.2 & 4.3 \\
\hline 885.6 & 56.4 & 60.9 & 56.3 & 4.6 \\
\hline 908.2 & 57.9 & 63.2 & 58.1 & 5.1 \\
\hline 934.4 & 59.6 & 65.4 & 60.3 & 5.1 \\
\hline 937.3 & 59.8 & 65.6 & 60.6 & 5.0 \\
\hline 957.4 & 61.2 & 66.8 & 62.3 & 4.5 \\
\hline 982.3 & 62.9 & 67.9 & 64.5 & 3.4 \\
\hline 1003.4 & 64.4 & 68.5 & 66.3 & 2.2 \\
\hline 1017.2 & 65.3 & 69.4 & 67.5 & 1.9 \\
\hline 1037.7 & 66.8 & 71.2 & 69.2 & 2.0 \\
\hline 1060.5 & 68.4 & 72.7 & 71.2 & 1.5 \\
\hline 1082.0 & 69.9 & 74.3 & 72.9 & 1.4 \\
\hline 1108.4 & 71.8 & 76.1 & 75.1 & 1.0 \\
\hline 1134.6 & 73.6 & 77.4 & 77.2 & 0.2 \\
\hline
\end{tabular}


TABLE 2. (continued)

\begin{tabular}{|c|c|c|c|c|}
\hline \multirow{2}{*}{$\begin{array}{c}\text { Sample Depth, } \\
\text { mbs }\end{array}$} & \multirow{2}{*}{$\begin{array}{c}\text { Gas Age, } \\
\mathrm{ka}\end{array}$} & \multicolumn{2}{|c|}{ Ice Age ka } & \multirow{2}{*}{$\begin{array}{l}\text { Correlated Ice Age } \\
\text { Lorius Ice Age, ka }\end{array}$} \\
\hline & & Correlated & Lorius ${ }^{a}$ & \\
\hline 1157.7 & 75.3 & 78.7 & 79.0 & -0.3 \\
\hline 1162.5 & 75.7 & 79.1 & 79.4 & -0.3 \\
\hline 1181.3 & 77.0 & 80.8 & 80.8 & 0.0 \\
\hline 1205.5 & 78.8 & 82.7 & 82.7 & 0.0 \\
\hline 1233.8 & 80.9 & 85.3 & 84.9 & 0.4 \\
\hline 1265.2 & 83.2 & 87.9 & 87.3 & 0.6 \\
\hline 1290.4 & 85.1 & 89.5 & 89.2 & 0.3 \\
\hline 1307.7 & 86.4 & 90.1 & 90.6 & -0.5 \\
\hline 1309.5 & 86.5 & 90.2 & 90.7 & -0.5 \\
\hline 1333.3 & 88.3 & 92.4 & 92.6 & -0.2 \\
\hline 1363.7 & 90.5 & 94.7 & 95.0 & -0.3 \\
\hline 1391.2 & 92.5 & 96.5 & 97.2 & -0.7 \\
\hline 1419.7 & 94.6 & 98.3 & 99.5 & -1.2 \\
\hline 1443.0 & 96.3 & 100.0 & 101.5 & -1.5 \\
\hline 1467.7 & 98.1 & 102.2 & 103.6 & -1.4 \\
\hline 1494.3 & 100.0 & 104.3 & 106.1 & -1.8 \\
\hline 1505.0 & 100.8 & 105.3 & 107.1 & -1.8 \\
\hline 1514.3 & 101.5 & 106.3 & 108.0 & -1.7 \\
\hline 1566.2 & 105.1 & 109.3 & 113.0 & -3.7 \\
\hline 1592.0 & 106.9 & 110.4 & 115.3 & -4.9 \\
\hline 1636.3 & 110.0 & 112.8 & 119.0 & -6.2 \\
\hline 1656.1 & 111.3 & 114.1 & 120.6 & -6.5 \\
\hline 1683.3 & 113.2 & 116.1 & 122.6 & -6.5 \\
\hline 1693.1 & 113.9 & 116.8 & 123.3 & -6.5 \\
\hline 1716.7 & 115.6 & 118.5 & 125.0 & -6.5 \\
\hline 1732.7 & 116.8 & 119.7 & 126.1 & -6.4 \\
\hline 1757.0 & 118.6 & 121.5 & 127.8 & -6.3 \\
\hline 1784.3 & 120.7 & 123.6 & 129.7 & -6.1 \\
\hline 1823.5 & 123.7 & 126.4 & 132.5 & -6.1 \\
\hline 1831.9 & 124.4 & 127.0 & 133.2 & -6.2 \\
\hline 1845.2 & 125.5 & 128.2 & 134.1 & -5.9 \\
\hline 1858.0 & 126.6 & 129.5 & 135.1 & -5.6 \\
\hline 1868.5 & 127.4 & 130.4 & 135.9 & -5.5 \\
\hline 1882.3 & 128.6 & 131.9 & 137 & -5.1 \\
\hline 1883.4 & 128.7 & 132.0 & 137.1 & -5.1 \\
\hline 1907.6 & 130.7 & 134.7 & 139.2 & -4.5 \\
\hline 1934.5 & 133.0 & 136.8 & 141.9 & -5.1 \\
\hline
\end{tabular}

Gas ages are those derived from the inverse correlation of the $818 \mathrm{O}_{\text {atm }}$ record with the $\delta 18 \mathrm{O}_{\mathrm{sw}}$ record from V19-30 core. The third column lists the ice ages from the correlation (see text for details). The last column lists the difference between the correlated ice ages and those from the Lorius et al. [1985]. Note that mbs indicates meters below the surface.

${ }^{a}$ Data are from Lorius et al. [1985]. 
warming at Vostok) at about $139 \mathrm{ka}$ in the SPECMAP chronology, while the $\delta 180$ of seawater begins to decrease at about $135 \mathrm{ka}$ in this chronology. Both the radiolarian chronology [Shackleton et al., 1992] and the diatom chronology [Pichon et al., 1992] indicate a lag at the end of the termination: $\mathrm{CO}_{2}$ reached its maximum value at about $129 \mathrm{ka}$ in these chronologies (and about $126 \mathrm{ka}$ in our chronology), while the $\delta 18 \mathrm{O}_{\mathrm{sw}}$ minimum was about 123-125 ka according to the SPECMAP chronology. The work summarized here thus indicates that $\mathrm{CO}_{2}$ changes led the ice volume decrease throughout the penultimate termination.

\section{COMPARISON OF AGE-DEPTH CURVES PROPOSED FOR THE VOSTOK ICE CORE}

Our age-depth curve, like others recently proposed for the Vostok ice core [Petit et al., 1990; Pichon et al., 1992; Shackleton et al., 1992], generally agrees very well with the "flow model" chronology proposed by Lorius et al. [1985]. The correlated ice age-depth curve deviates from the Lorius et al. [1985] curve by more than $2 \mathrm{kyr}$ between 350 and $1000 \mathrm{mbs}$ and again below $1500 \mathrm{mbs}$ (Figure 5). Our correlation of Vostok into the SPECMAP chronology requires increasing the Lorius et al. [1985] age for the beginning of termination I by 5 kyr and decreasing the age for the start of termination II by $5 \mathrm{kyr}$. Our chronology is in excellent agreement with the Lorius et al. [1985] chronology for the interval between 70 and $110 \mathrm{ka}$ (roughly 1050 to $1580 \mathrm{mbs}$ ).

Our age-depth curve is compared with similar curves recently proposed by other workers (Figure 5). Petit et al. [1990] picked control points by aligning the "magnetic flux" record from the marine sediment core RC11-120 with dust accumulation near Vostok (we refer to this correlation technique as the dust correlation). Pichon et al. [1992] picked control points by aligning the temperature - depth record for Vostok with the record of SST versus age

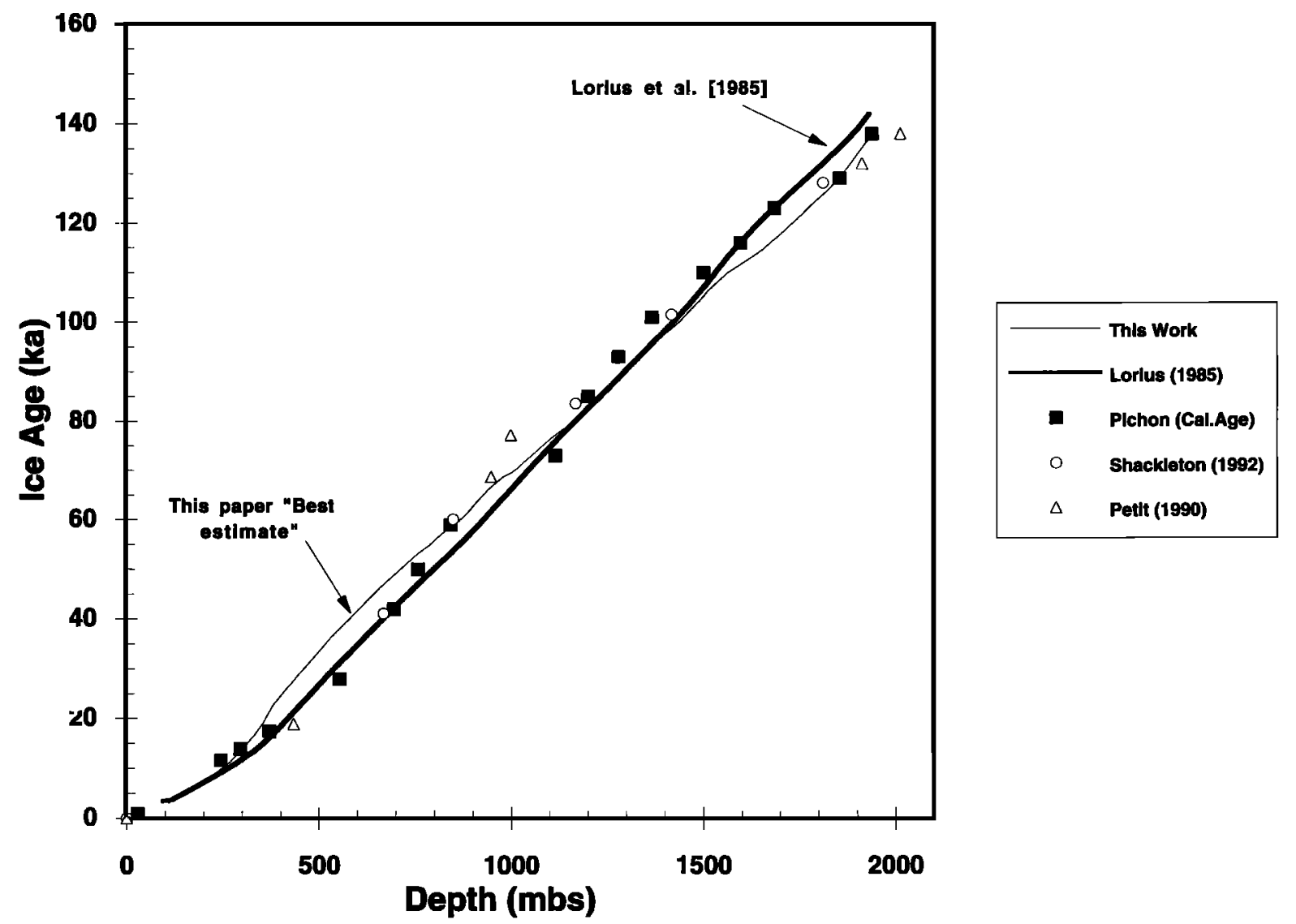

Fig. 5. Various ice age versus depth profiles for the Vostok ice core. The curve labeled "Best estimate" is based on our $\delta 180$ correlation. Also plotted are the estimate by Lorius et al. [1985] and the "control points" of Pichon et al. [1992] (diatom), Shackleton et al. [1992] (radiolaria), and Petit et al. [1990] (dust). In general, all recent correlations agree with the original model of Lorius et al. [1985] within stated uncertainties. 
for southern ocean core MD 84-551. SST for this core was inferred from diatom taxonomy using a transfer function (the diatom correlation). Shackleton et al. [1992] picked control points by aligning the temperature-depth record for Vostok with the SST record of core RC11-120, determined from radiolarian taxonomy (the radiolarian correlation) [Hays et al., 1976a,b]. For this latter record we have plotted only control points associated with maximum SST values; SST minima might not be faithfully reflected given the limited temperature range of radiolarian species.

Between about 290- and 360-m depth, the interval covering the last deglaciation, our proposed agedepth curve diverges strongly from that of Lorius et al. [1985]. We assign the 357-m depth an age of 20 kyr, compared to the flow model age of $15 \mathrm{kyr}$. As noted above, the Petit et al. [1990] chronology (dust) is in fair agreement with the flow chronology over this interval. The diatom timescale in this depth interval is based on ${ }^{14} \mathrm{C}$ dates rather than the short SPECMAP chronology (which is independent of the ${ }^{14} \mathrm{C}$ chronology). To allow a more direct comparison, we note that Martinson et al. [1987] assigned an age of $17.9 \mathrm{kyr}$ for the last glacial maximum (event 2.2 in Table 2). This age is in good agreement with a sidereal age of about $18 \mathrm{kyr}$ for the $\delta 18 \mathrm{O}_{\text {foram }}$ maximum, based on ${ }^{14} \mathrm{C}$ dating of many foraminiferal $\delta 180$ curves [Sarnthein et al., 1992] after converting ${ }^{14} \mathrm{C}$ ages to absolute ages based on the work of Bard et al. [1990a]. When we convert the MD84-551 timescale from ${ }^{14} \mathrm{C}$ ages to absolute ages, the start of the last termination moves from 15 $\mathrm{ka}\left({ }^{14} \mathrm{C}\right)$ to $17 \mathrm{ka}$ (calendar). If we were to recorrelate the MD84-551 SST and Vostok temperature records on the calendar timescale, the Vostok temperature-age record would be in better agreement with the temperature-age record from the Byrd ice core, where the beginning of the termination is dated between 16 and $18 \mathrm{ka}$ [Beer et al., 1992].

Between about 400 - and 800 -m depth, corresponding to correlated SPECMAP ages of 25$55 \mathrm{ka}$, our proposed correlation ages are highly uncertain. Comparing $\delta 18 \mathrm{O}_{\mathrm{atm}}$ and $\delta 18 \mathrm{O}_{\mathrm{sw}}$ values over this interval is problematic for two reasons. First, $\delta 18 \mathrm{O}_{s w}$ variations are small (total range of $0.35 \%$ ), so that there is not a strong signal. Second, sample resolution is poor because of substandard ice quality in this interval; between 500 - and 650-m depth we have analyzed only 2 samples. This poor basis for correlation translates into two anomalous results in the correlated chronology. The $\delta 18 \mathrm{O}_{\mathrm{atm}}$ minimum at 533-m depth, derived from a single sample, is not correlated into the $\delta 18 \mathrm{O}_{\mathrm{sw}}$ minimum at $32 \mathrm{ka}$ but precedes it by about $5 \mathrm{kyr}$ (Figure 4). Additionally, the $\mathrm{CH}_{4}$ concentration maximum at $625-\mathrm{m}$ depth in the Vostok core, dated at $32 \mathrm{ka}$ in the Lorius et al. [1985] chronology, is redated to $37 \mathrm{ka}$ by our correlation with the SPECMAP chronology. This age is $6 \mathrm{kyr}$ older than the maximum in low- latitude simulated precipitation calculated by Prell and Kutzbach [1987] to coincide with the maximum in northern hemisphere summer insolation at $31 \mathrm{ka}$. There is a strong precession signal in the $\mathrm{CH}_{4}$ concentration variations [Chappellaz et al., 1990]. Chappellaz et al. [1990] explained the relationship between $\mathrm{CH}_{4}$ maxima and maxima in simulated precipitation by suggesting that higher precipitation leads to higher rates of $\mathrm{CH}_{4}$ production. All other $\mathrm{CH}_{4}$ concentration maxima in the Vostok record are closely aligned with northern hemisphere summer insolation maxima given our correlated ages [M. Bender et al., The Dole effect and its variations during the last 130,000 years as measured in the Vostok ice core, submitted to Global Biogeochemical Cycles, 1993). The fact that the $\mathrm{CH}_{4}$ maximum at 625-m depth precedes the insolation maximum by 6 $\mathrm{kyr}$ is another cause for concern about errors in our correlated chronology between 25 and $55 \mathrm{ka}$. Our correlated ages are less reliable for this section than for any other part to the Vostok core.

In the depth interval from $800 \mathrm{~m}$ to $1200 \mathrm{~m}$ (55-80 ka), ages inferred from $\delta 180$ of $\mathrm{O}_{2}$, diatoms, radiolaria, and dust scatter considerably but are all on average about $5 \mathrm{kyr}$ older than ages at the same depth estimated from the flow model (Figure 6). In this depth interval, none of the correlation methods would be expected to work well, because variations in paleotemperature, $\delta 18 \mathrm{O}$ of $\mathrm{O}_{2}$ and seawater, and dust flux are all small and therefore do not provide a strong basis for intercomparing records. In general, it can be said that the various correlation approaches give about the same accumulation rates between 800 and $1200 \mathrm{~m}$ as the flow model but give older absolute ages.

Between 1200 and $1600 \mathrm{~m}$, ages from the flow model and $\delta 180$ stratigraphy are in good agreement, and ages from dust, diatoms, and radiolaria are higher by about 4 kyr. Perhaps the most accurately dated depth in this interval is at about $1200 \mathrm{~m}$, where the radiolarian record shows a distinct temperature maxima and $\delta 18 \mathrm{O}$ of $\mathrm{O}_{2}$ shows clear minima corresponding to stage $5 \mathrm{a}$. At this depth, dates from the flow model, from $\delta 18 \mathrm{O}$ of $\mathrm{O}_{2}$, and from radiolaria agree to within $3 \mathrm{kyr}$. Diatom ages are higher than $\delta 18 \mathrm{O}$ ages by about $3 \mathrm{kyr}$, and this may reflect the fact that the diatom temperature record shows more variability than, and is not easily correlated with, the ice core record in this time interval.

By $1700 \mathrm{~m}$, corresponding approximately to the beginning of stage $5 \mathrm{~d}$, the various age-depth curves show increased divergence. Diatom ages agree well with the flow chronology, while $\delta 18 \mathrm{O}$ ages are about 7 kyr younger. We believe that the $\delta 18 \mathrm{O}$ ages are less reliable, because the $\delta 18 \mathrm{O}_{\text {atm }}$ is clearly not following changes in $\delta 18 \mathrm{O}_{\mathrm{sw}}$ such that much of the variability in $\delta 18 \mathrm{O}_{\mathrm{atm}}$ must be due to changes in the $M-D$ effect. The radiolarian chronology of Shackleton et al. [1992] brings the time of the 


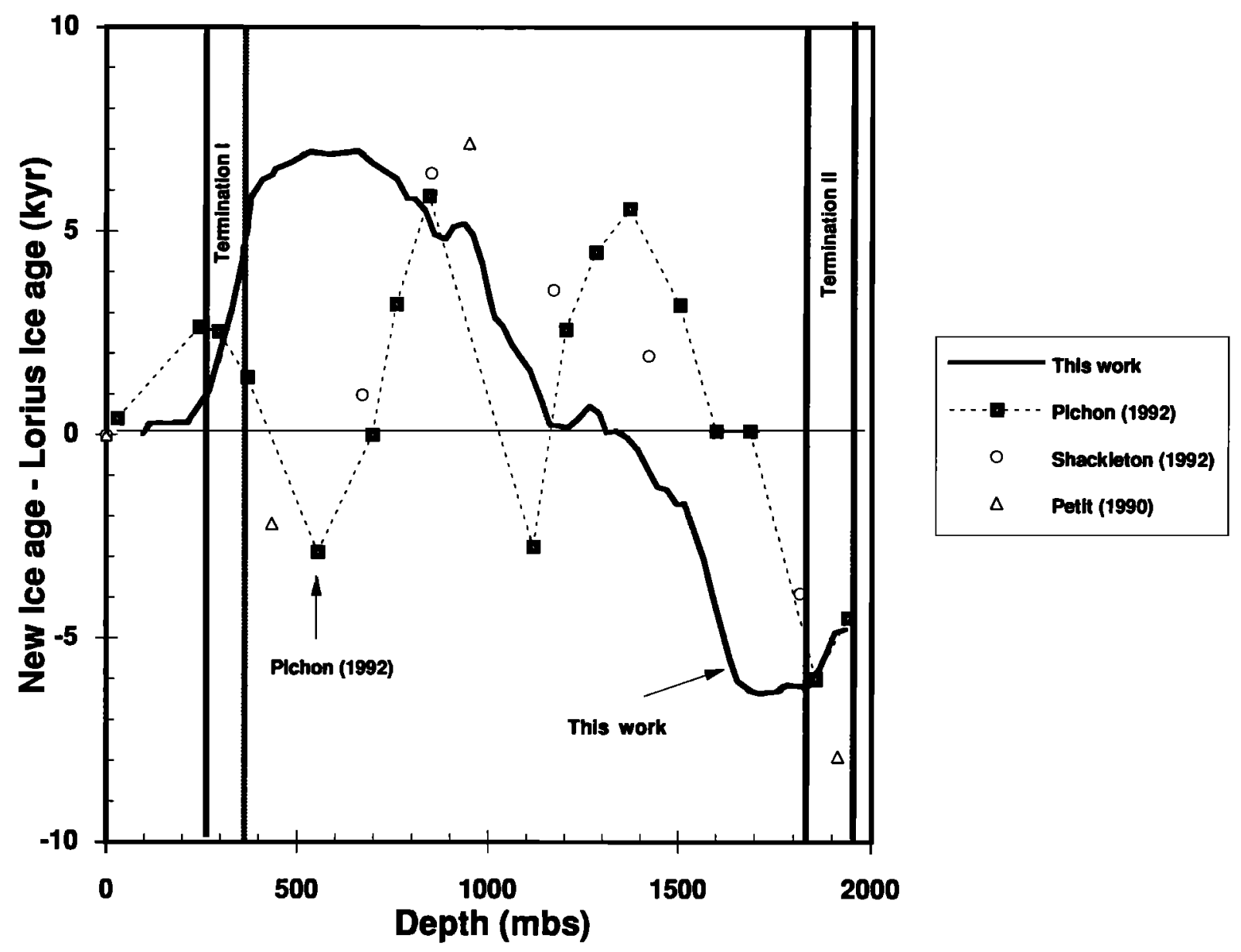

Fig. 6. Differences between the original Lorius et al. [1985] age estimates and those from recent correlation studies. The thick line illustrates the results from the $\delta 180$ (ice) correlation. The dashed line illustrates the paleoaccumulation rate predicted from the Pichon et al. [1992] (diatom) correlation. Also plotted are the "control points" from Shackleton et al. [1992] (circles) and Petit et al. [1990] (triangles). Terminations I and II are marked for reference. During termination I, both the diatom and 8180 correlations indicate that the ice ages are older than corresponding ages from the Lorius et al. [1985] timescale. For termination II, all correlated ages are all about $7 \mathrm{kyr}$ younger than the Lorius et al. [1985] timescale. During the last glacial period, the correlated ages vary by less than $\pm 6 \mathrm{kyr}$ from the original Lorius et al. [1985] chronology.

decrease in $p \mathrm{CO}_{2}$ observed at Vostok into line with the time of the $\Delta \delta 13 \mathrm{C}$ (planktonic-benthic) increase observed in both their stacked record as well as their V19-30 record. This last result must be viewed with caution, as the $\Delta$ age estimates used by Shackleton et al. [1992] were not consistent with their modified ice age-depth curve.

At 1850 -m depth (stage 5e), radiolarians, diatoms, and $\delta 18 \mathrm{O}$ all give concordant ages which are younger than that of the flow model chronology.
Radiolarians and diatoms give ages of about $128 \mathrm{ka}$ for the temperature minimum at stage $5 \mathrm{e}$, in good agreement with the $\delta 18 \mathrm{O}$ age of about $126 \mathrm{ka}$. The age estimated from the flow model is about $133 \mathrm{ka}$. The dust age at a slightly deeper control point is even younger than the $\delta 180$ age. Pichon et al. [1992] and Shackleton et al. [1992] have shown that Vostok temperature and $p \mathrm{CO}_{2}$ values can be brought into phase with southern ocean SST and foram $\Delta \delta{ }^{13} \mathrm{C}$ values by invoking an age for the temperature 
minimum which is about 5-10 kyr younger than that of the flow chronology. Our work supports their conclusions.

\section{COMPARISON OF OTHER DEEP-SEA AND VOSTOK CLIMATE RECORDS}

\section{Southern Ocean Sea Surface Temperature Records Correlated to the Vostok Inversion Layer Temperature}

We now compare temperature records from Antarctica and the southern ocean to investigate the validity of our underlying premise which is that $\delta 18 \mathrm{O}_{\mathrm{atm}}$ may be used as a proxy for $\delta 18 \mathrm{O}_{\mathrm{sw}}$. Because the temperature above the Antarctic inversion layer is controlled by the transport of latent and sensible heat from the southern ocean, the record of Antarctic inversion layer temperature is believed to have been similar to the SST record for the southern ocean over the same period [Pichon et al., 1992]. The $\delta \mathrm{D}$ of the precipitation over Antarctica has been shown to be controlled by the temperature at the top of the inversion layer [Jouzel and Merlivat, 1984]. The record of $\delta \mathrm{D}$ variations along the Vostok ice core have been used to construct a record of the inversion layer temperature over the Vostok area [Jouzel et al., 19871 .

We assume that there is a strong relationship between southern ocean sea surface temperature and the temperature above the inversion layer. We then test the age-depth curve we derived for Vostok by comparing the Vostok curve of inversion layer temperature versus age against the southern ocean sea surface temperature-age curve (inferred from the temperature dependence of planktonic microfossils). The degree of concordance is a measure of the fidelity of our age-depth curve and the validity of the assumption that temperature is faithfully recorded by the different proxy data (diatom and radiolarian SST and $\delta \mathrm{D}_{\text {ice }}$ ).

Sea surface temperature records from RC11-120 (44031'S, $\left.79^{\circ} 52^{\prime} \mathrm{E}\right)$ [Hays et al., 1976a, $b$; Lozano and Hays, 1976] and MD88-770 (46.5, 96 $\left.{ }^{\circ} \mathrm{E}\right)(\mathrm{L}$. Labeyrie et al., Changes in southern ocean hydrology over the last $230 \mathrm{kyr}$ as recorded in core MD88-770, manuscript in preparation, 1993) are plotted in Figure 7. Relevant data from MD88-770 are also tabulated in Table 3. The temperature records are estimated from data relating the distribution of microfossils recovered from sediment core tops to the overlying sea surface temperature. The diatom record is believed to represent summer SST to about $\pm 1{ }^{\circ} \mathrm{C}$ [Pichon et al., 1992]. For both records, we estimated ages by correlating $\delta 18 \mathrm{O}_{\text {foram }}{ }^{-}$ depth curves into the SPECMAP stacked $\delta 18 \mathrm{O}_{\text {foram }}{ }^{-}$ age curve [Pisias et al., 1984; Martinson et al., 1987]. We then use the age versus depth relation from the $\delta 180$ correlation to transfer the SST record from the depth domain to the time domain. Glacial/interglacial sea surface temperature changes inferred from the RC11-120 and MD88-770 records are about $6^{\circ}-8^{\circ} \mathrm{C}$.

Sea surface temperature estimates for RC11-120 are systematically higher, by about $4{ }^{\circ} \mathrm{C}$, than temperatures estimated for MD88-770. One reason is that despite their similar latitude, MD88-770 is actually located about $3^{\circ}$ closer to the Polar Front than RC11-120. Another reason is that the radiolarian transfer function reflects temperatures below $7^{\circ} \mathrm{C}$ very poorly, while the diatom transfer function loses discrimination above about $10^{\circ} \mathrm{C}$. We suspect that the RC11-120 record may be overestimating glacial temperatures and adopt the SST record from MD88-770 for comparison with Vostok. Both RC11-120 and MD88-770 are presently located in the subantarctic water mass which is bounded to the south by the Antarctic Polar Front and to the north by the Subtropical Convergence. Summer water temperatures between $10^{\circ} \mathrm{C}$ and $14^{\circ} \mathrm{C}$ along with salinities of 34.3-34.9\%o normally characterize the northern boundary of subantarctic water which is presently located at about $40^{\circ}$ S. The Antarctic Polar Front has water temperatures of between 4 and $10^{\circ} \mathrm{C}$ with salinities between 34.0 to $34.6 \%$. The location of the Antarctic Polar Front is presently located just south of $50^{\circ} \mathrm{S}$ latitude [Lozano and Hays, 1976].

Interpreting sea surface temperature records from this region of the southern ocean is problematic, because some variability may be related to localized changes in the hydrographic setting, rather than large-scale changes in SST. In particular, migration of the Polar Front across our site, rather than regional changes in SST, may be responsible for much of the variability we observe. Two studies in particular have looked at the movement of the Polar Front in this region of the southern ocean; Hays et al. [1976b] studied the distribution of radiolaria, while Howard and Prell [1992] looked at the foraminiferal assemblages to determine the position of the Polar Front during the last glacial maximum period relative to the present day location. Both studies concluded that the Antarctic Polar Front was located about 40-70 north of its present-day position during the last glacial period. Given that MD88-770 is located about $6^{\circ}$ north of the present day Antarctic Polar Front, it is conceivable that some of the SST variability observed in Figure 7 is related to the passage of the front over the site. Nevertheless, we believe that the influence of the Polar Front has not compromised this SST record substantially for three reasons: (1) The Subantarctic assemblage has dominated the diatom population throughout the 150ka record, as exhibited by its high-factor loadings $(>62 \%)$, (2) the amount of ice-rafted debris does not increase during glacial periods, and (3) the abundance of the four diatom species which are 


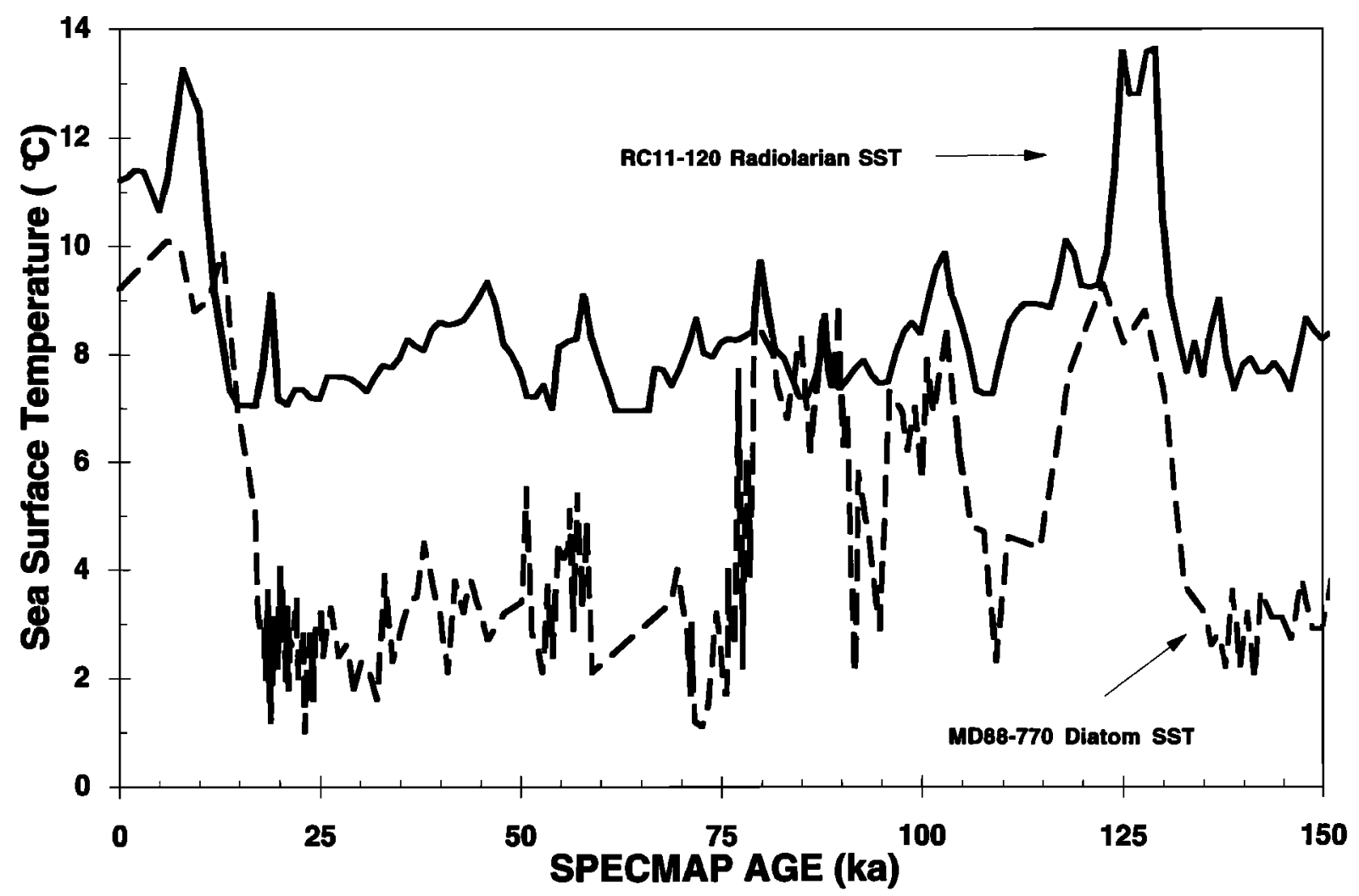

Fig. 7. Sea surface temperature (SST) records from RC11-120 (440S, 80E) (solid line) and MD88-770 (46. $\left.5,9^{\circ} \mathrm{E}\right)$ (dashed line) both plotted on the SPECMAP timescale. The RC11-120 record is from Hays et al. [1976a] based on a radiolarian transfer function. The SST record from MD88-770 is based on a diatom transfer function [Pichon et al., 1992]. The two records show similar glacial to interglacial temperature shifts of $6^{\circ}-8^{\circ} \mathrm{C}$. The SST record from RC11-120 is systematically higher than that of MD88-770. One explanation for this systematic difference is that the radiolarian transfer function is not reliable at temperatures below $7^{\circ} \mathrm{C}$.

associated with sea ice (Nitzschia curta, Actinocyclus actinochilus, Nitzchia sublineata, and Nitzchia cylindrus ) remains low. Based on this evidence we believe that the SST record from MD88-770 can be used as a reasonable approximation of the SST record of the subantarctic waters north of the Polar Front.

\section{Ice Core Records of Atmospheric Temperatures}

Over the Antarctic continent, there is a 300- to 700 $m$ layer of air in which the temperature increases with increasing altitude. Above this temperature inversion, temperatures decrease according to the adiabatic lapse rate. The strength of the inversion layer, as measured by the difference between the surface temperature and the temperature just above the inversion layer, is about $5^{\circ} \mathrm{C}$ near the coast [Phillpot and Zillman, 1970]. Maximum temperature differences reach $20^{\circ} \mathrm{C}$ near Vostok. As noted above, the accumulation rate and the isotopic composition of the precipitation are related to the temperature just above the inversion layer where the precipitation is formed [Robin, 1977; Jouzel and Merlivat, 1984]. We adopt the inversion layer temperature record from Jouzel et al. [1987] which is based on the measured $\delta D$ profile from the Vostok core for comparison with the SST from MD88-770. In Figure 8 we have plotted the Vostok temperature record using our correlated ice age-depth relation. The SST record is plotted using the SPECMAP timescale as in Figure 7. These two records show glacial/interglacial temperature changes of $6^{\circ}-8^{\circ} \mathrm{C}$. Plotted in this fashion, the two records have a correlation coefficient of 0.72 , implying that $52 \%$ of the variance is shared by the two records. When these two data sets are compared using the Lorius et al. [1985] chronology, the correlation coefficient is 0.54 (i.e., only $\sim 30 \%$ shared variance). We interpret the higher degree of correlation between the two records using our common temporal framework as evidence that the Vostok record is better correlated with the deep-sea record using the chronology derived here from $\delta 18 \mathrm{O}_{\mathrm{atm}}$ data. We make no claim for having improved the absolute chronology. 
TABLE 3. Data From Deep-Sea Sediment Core MD88-770

\begin{tabular}{|c|c|c|c|}
\hline $\begin{array}{l}\text { Sample Depth, } \\
\text { cm }\end{array}$ & $\begin{array}{l}\text { Age, } \\
\text { ka }\end{array}$ & $\begin{array}{c}\text { Benthic } \\
\delta 180 . \% \varrho \text { PDB }\end{array}$ & $\begin{array}{c}\text { Sea Surface } \\
\text { Temperature, }{ }^{\circ} \mathrm{C}\end{array}$ \\
\hline 0 & 0.0 & 3.55 & 9.2 \\
\hline 10 & 6.0 & 3.50 & 10.1 \\
\hline 20 & 7.7 & 3.55 & 9.9 \\
\hline 30 & 9.4 & 3.83 & 8.8 \\
\hline 40 & 11.1 & 3.87 & 9.0 \\
\hline 50 & 13.0 & 4.49 & 9.9 \\
\hline 60 & 15.0 & 4.72 & 6.9 \\
\hline 70 & 17.0 & 5.16 & 5.1 \\
\hline 80 & 17.3 & 5.01 & 3.2 \\
\hline 90 & 17.7 & 5.10 & 2.9 \\
\hline 100 & 18.0 & 4.92 & 3.0 \\
\hline 110 & 18.3 & 5.02 & 2.0 \\
\hline 120 & 18.6 & 5.14 & 3.6 \\
\hline 130 & 18.9 & 5.03 & 1.2 \\
\hline 136 & 19.1 & 5.19 & - \\
\hline 140 & 19.3 & 4.90 & 3.1 \\
\hline 150 & 19.6 & 5.10 & 2.7 \\
\hline 154 & 19.7 & - & 2.2 \\
\hline 156 & 19.8 & - & 2.4 \\
\hline 158 & 19.9 & - & 3.3 \\
\hline 160 & 19.9 & 5.13 & 3.2 \\
\hline 162 & 20.0 & - & 3.1 \\
\hline 164 & 20.0 & - & 3.0 \\
\hline 166 & 20.1 & - & 4.1 \\
\hline 170 & 20.2 & 5.09 & 2.7 \\
\hline 174 & 20.4 & - & 3.6 \\
\hline 176 & 20.4 & 5.18 & - \\
\hline 178 & 20.5 & - & 3.2 \\
\hline 180 & 20.6 & 5.12 & 2.9 \\
\hline 184 & 20.7 & - & 2.3 \\
\hline 186 & 20.8 & 5.10 & - \\
\hline 190 & 20.9 & 5.16 & 1.9 \\
\hline 194 & 21.0 & . & 3.3 \\
\hline 196 & 21.1 & 5.02 & - \\
\hline 200 & 21.2 & - & 1.8 \\
\hline 204 & 21.3 & - & 2.7 \\
\hline 210 & 21.5 & 5.15 & 2.6 \\
\hline 214 & 21.7 & . & 2.7 \\
\hline 220 & 21.9 & 5.06 & 3.2 \\
\hline 224 & 22.0 & 5.04 & 2.9 \\
\hline 226 & 22.1 & 5.05 & 2.8 \\
\hline 230 & 22.2 & - & 3.5 \\
\hline 234 & 22.3 & - & 2.0 \\
\hline 236 & 22.4 & 5.04 & \\
\hline 240 & 22.5 & 5.06 & 2.1 \\
\hline 244 & 22.6 & & 2.4 \\
\hline 246 & 22.7 & 4.98 & - \\
\hline 250 & 22.8 & - & 2.4 \\
\hline 254 & 23.0 & - & 2.8 \\
\hline 260 & 23.2 & - & 1.0 \\
\hline 264 & 23.3 & - & 1.4 \\
\hline 270 & 23.5 & - & 2.2 \\
\hline
\end{tabular}


TABLE 3. (continued)

\begin{tabular}{|c|c|c|c|}
\hline $\begin{array}{l}\text { Sample Depth, } \\
\mathrm{cm}\end{array}$ & $\begin{array}{c}\text { Age, } \\
\text { ka }\end{array}$ & $\begin{array}{c}\text { Benthic } \\
\delta 180 \% \% \text { PDB }\end{array}$ & $\begin{array}{c}\text { Sea Surface } \\
\text { Temperature, }{ }^{\circ} \mathrm{C}\end{array}$ \\
\hline 274 & 23.6 & - & 2.4 \\
\hline 280 & 23.8 & 5.08 & 2.8 \\
\hline 284 & 23.9 & & 2.6 \\
\hline 286 & 24.0 & 5.05 & - \\
\hline 290 & 24.1 & 4.99 & 2.3 \\
\hline 294 & 24.3 & & 1.6 \\
\hline 298 & 24.4 & 4.92 & - \\
\hline 300 & 24.5 & 4.94 & 2.8 \\
\hline 302 & 24.5 & - & 2.8 \\
\hline 306 & 24.6 & 5.04 & - \\
\hline 310 & 24.8 & - & 3.1 \\
\hline 316 & 25.0 & 4.98 & \\
\hline 320 & 25.1 & 4.96 & 3.2 \\
\hline 330 & 25.4 & 4.80 & 2.4 \\
\hline 340 & 26.4 & - & 3.3 \\
\hline 350 & 27.4 & 4.86 & 2.4 \\
\hline 360 & 28.3 & - & 2.6 \\
\hline 366 & 28.9 & 4.95 & . \\
\hline 370 & 29.3 & - & 1.8 \\
\hline 376 & 29.9 & 4.82 & - \\
\hline 380 & 30.3 & 4.65 & 2.3 \\
\hline 386 & 30.9 & 4.39 & - \\
\hline 390 & 31.3 & & 2.1 \\
\hline 396 & 31.8 & 4.69 & - \\
\hline 400 & 32.2 & - & 1.6 \\
\hline 406 & 32.8 & 4.76 & - \\
\hline 410 & 33.2 & - & 3.9 \\
\hline 420 & 34.2 & - & 2.3 \\
\hline 426 & 34.8 & 4.83 & . \\
\hline 430 & 35.1 & 4.83 & 2.9 \\
\hline 434 & 35.5 & 4.70 & - \\
\hline 440 & 36.1 & 4.80 & 3.4 \\
\hline 446 & 36.7 & 4.78 & - \\
\hline 450 & 37.1 & 4.77 & 3.5 \\
\hline 456 & 37.7 & 4.78 & - \\
\hline 460 & 38.1 & 4.74 & 4.5 \\
\hline 466 & 38.6 & 4.70 & - \\
\hline 470 & 39.0 & 4.72 & 3.8 \\
\hline 476 & 39.6 & 4.72 & - \\
\hline 480 & 40.0 & 4.82 & 3.2 \\
\hline 486 & 40.6 & 4.86 & - \\
\hline 490 & 41.0 & - & 2.1 \\
\hline 496 & 41.6 & 4.76 & - \\
\hline 500 & 41.9 & 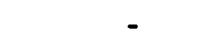 & 3.8 \\
\hline 510 & 42.9 & 4.76 & 3.2 \\
\hline 516 & 43.5 & 4.71 & - \\
\hline 520 & 43.9 & 4.68 & 3.8 \\
\hline 526 & 45.2 & 4.70 & - \\
\hline 530 & 46.0 & - & 2.7 \\
\hline 536 & 47.3 & 4.70 & - \\
\hline 540 & 48.1 & - & 3.2 \\
\hline
\end{tabular}


TABLE 3. (continued)

\begin{tabular}{|c|c|c|c|}
\hline $\begin{array}{l}\text { Sample Depth, } \\
\mathrm{cm}\end{array}$ & $\begin{array}{l}\text { Age, } \\
\text { ka }\end{array}$ & $\begin{array}{c}\text { Benthic } \\
\delta 180 \% \% \text { PDB }\end{array}$ & $\begin{array}{c}\text { Sea Surface } \\
\text { Temperature, }{ }^{\circ} \mathrm{C}\end{array}$ \\
\hline 550 & 50.2 & 4.60 & 3.4 \\
\hline 556 & 50.6 & 4.64 & - \\
\hline 560 & 50.9 & 4.63 & 5.5 \\
\hline 570 & 51.5 & - & 2.8 \\
\hline 580 & 52.2 & 4.66 & 2.6 \\
\hline 590 & 52.8 & 4.72 & 2.1 \\
\hline 600 & 53.5 & 4.68 & 3.7 \\
\hline 610 & 54.1 & - & 2.4 \\
\hline 616 & 54.5 & 4.74 & - \\
\hline 620 & 54.8 & 4.52 & 4.4 \\
\hline 626 & 55.2 & 4.71 & $\overline{-}$ \\
\hline 630 & 55.5 & 4.60 & 4.2 \\
\hline 640 & 56.0 & 4.60 & 4.4 \\
\hline 644 & 56.3 & - & 5.1 \\
\hline 646 & 56.4 & 4.66 & - \\
\hline 650 & 56.6 & - & 2.9 \\
\hline 652 & 56.7 & - & 3.0 \\
\hline 656 & 57.0 & 4.70 & - \\
\hline 660 & 57.2 & - & 5.4 \\
\hline 670 & 57.8 & 4.62 & 3.3 \\
\hline 680 & 58.4 & 4.70 & 4.9 \\
\hline 690 & 59.0 & 4.71 & 2.1 \\
\hline 696 & 64.1 & 4.86 & - \\
\hline 700 & 68.8 & 4.74 & 3.4 \\
\hline 704 & 69.6 & - & 4.0 \\
\hline 710 & 70.8 & 4.89 & 2.8 \\
\hline 714 & 71.2 & - & 1.7 \\
\hline 716 & 71.4 & 4.74 & 3.0 \\
\hline 720 & 71.7 & 4.54 & 1.2 \\
\hline 726 & 72.2 & 4.44 & - \\
\hline 730 & 72.6 & 4.56 & 1.1 \\
\hline 736 & 73.1 & 4.68 & - \\
\hline 740 & 73.5 & 4.53 & 1.6 \\
\hline 750 & 74.4 & 4.40 & 3.2 \\
\hline 754 & 74.8 & - & 2.9 \\
\hline 760 & 75.4 & 4.19 & 1.8 \\
\hline 762 & 75.6 & - & 1.7 \\
\hline 764 & 75.8 & - & 1.7 \\
\hline 766 & 76.0 & - & 4.0 \\
\hline 768 & 76.1 & . & 3.1 \\
\hline 770 & 76.3 & 4.29 & 3.1 \\
\hline 774 & 76.7 & - & 2.6 \\
\hline 780 & 77.3 & 4.32 & 7.7 \\
\hline 784 & 77.7 & - & 2.2 \\
\hline 790 & 78.3 & 4.32 & 6.1 \\
\hline 794 & 78.7 & - & 3.9 \\
\hline 798 & 79.1 & - & 6.3 \\
\hline 800 & 79.3 & 4.21 & 8.7 \\
\hline 802 & 79.8 & - & 8.5 \\
\hline 808 & 81.6 & - & 8.0 \\
\hline 810 & 82.2 & 4.18 & 7.4 \\
\hline 814 & 83.4 & - & 6.8 \\
\hline
\end{tabular}


TABLE 3. (continued)

\begin{tabular}{|c|c|c|c|}
\hline $\begin{array}{l}\text { Sample Depth, } \\
\mathrm{cm}\end{array}$ & $\begin{array}{l}\text { Age, } \\
\text { ka }\end{array}$ & $\begin{array}{c}\text { Benthic } \\
\delta 180 \% \text { PDB }\end{array}$ & $\begin{array}{c}\text { Sea Surface } \\
\text { Temperature, }{ }^{\circ} \mathrm{C}\end{array}$ \\
\hline 820 & 85.1 & 4.18 & 8.3 \\
\hline 824 & 86.3 & - & 6.2 \\
\hline 830 & 88.0 & 4.28 & 8.8 \\
\hline 832 & 88.6 & - & 7.7 \\
\hline 834 & 89.2 & - & 7.3 \\
\hline 836 & 89.8 & - & 8.8 \\
\hline 838 & 90.4 & - & 6.3 \\
\hline 840 & 91.0 & 4.34 & 6.9 \\
\hline 842 & 91.2 & - & 4.4 \\
\hline 844 & 91.5 & - & 3.5 \\
\hline 846 & 91.7 & - & 2.1 \\
\hline 848 & 92.0 & - & 2.9 \\
\hline 850 & 92.3 & 4.30 & 5.8 \\
\hline 860 & 93.6 & 4.23 & 4.6 \\
\hline 870 & 94.9 & 4.25 & 2.9 \\
\hline 880 & 96.2 & 4.16 & 7.3 \\
\hline 890 & 97.8 & 4.12 & 6.9 \\
\hline 894 & 98.4 & - & 6.2 \\
\hline 900 & 99.4 & 4.18 & 7.0 \\
\hline 902 & 100.2 & - & 5.7 \\
\hline 904 & 100.9 & - & 7.9 \\
\hline 906 & 101.7 & - & 6.9 \\
\hline 910 & 103.3 & 4.13 & 8.4 \\
\hline 920 & 104.8 & 4.33 & 6.3 \\
\hline 930 & 106.3 & 4.32 & - \\
\hline 930 & 106.3 & - & 4.8 \\
\hline 940 & 107.8 & 4.28 & 4.7 \\
\hline 950 & 109.3 & 4.24 & 2.3 \\
\hline 960 & 110.8 & 4.30 & 4.6 \\
\hline 970 & 114.7 & 4.05 & 4.4 \\
\hline 980 & 118.6 & 3.71 & 7.7 \\
\hline 990 & 122.6 & 3.28 & 9.3 \\
\hline 1000 & 125.2 & 3.38 & 8.2 \\
\hline 1010 & 127.8 & 4.00 & 8.8 \\
\hline 1020 & 130.3 & 4.64 & 7.2 \\
\hline 1030 & 132.7 & 4.32 & 3.7 \\
\hline 1040 & 135.1 & 5.02 & 3.2 \\
\hline 1050 & 136.0 & 4.89 & 2.6 \\
\hline 1060 & 136.9 & 5.00 & 2.8 \\
\hline 1070 & 137.8 & - & 2.2 \\
\hline 1080 & 138.7 & 4.94 & 3.6 \\
\hline 1090 & 139.6 & 5.01 & 2.2 \\
\hline 1100 & 140.5 & 4.91 & 3.2 \\
\hline 1110 & 141.4 & 4.92 & 2.0 \\
\hline 1120 & 142.3 & 4.75 & 3.6 \\
\hline 1130 & 143.6 & 4.84 & 3.1 \\
\hline 1140 & 144.9 & 4.86 & 3.1 \\
\hline 1150 & 146.1 & 4.84 & 2.7 \\
\hline 1160 & 147.4 & 4.86 & 3.8 \\
\hline 1170 & 148.7 & 4.88 & 2.9 \\
\hline 1180 & 150.0 & - & 2.9 \\
\hline 1190 & 151.3 & - & 3.9 \\
\hline
\end{tabular}


TABLE 3. (continued)

\begin{tabular}{cccc}
\hline $\begin{array}{c}\text { Sample Depth, } \\
\text { cm }\end{array}$ & $\begin{array}{c}\text { Age, } \\
\text { ka }\end{array}$ & $\begin{array}{c}\text { Benthic } \\
\text { 8180\% } \% \text { PDB }\end{array}$ & $\begin{array}{c}\text { Sea Surface } \\
\text { Temperature. }{ }^{\circ} \mathrm{C}\end{array}$ \\
\hline 1196 & 152.1 & 4.92 & - \\
1200 & 152.6 & - & 3.1 \\
1210 & 153.4 & - & 2.0 \\
1220 & 154.2 & - & 1.5 \\
1226 & 154.7 & 4.74 & - \\
1230 & 155.0 & - & 1.5 \\
1240 & 155.8 & - & 0.5 \\
1250 & 156.6 & 4.43 & - \\
1250 & 156.6 & - & 1.7 \\
1256 & 157.0 & 4.58 & - \\
1260 & 157.4 & 4.72 & - \\
1260 & 157.4 & - & 1.5 \\
1270 & 158.2 & 4.70 & - \\
1270 & 158.2 & - & 1.9 \\
1280 & 159.0 & - & 2.8 \\
1290 & 159.7 & - & 1.7 \\
1300 & 160.5 & - & 3.1
\end{tabular}

\footnotetext{
Ages are based on the correlation into the stacked SPECMAP $\delta 18 O_{\text {foram }}$ record. The $\delta 18 \mathrm{O}_{\text {foram }}$ data is a composite record of the Cibicides and Uvigerina species. The last column lists the sea surface temperatures as deduced from the diatom transfer function D166/34/4 [Pichon et al., 1992]. PDB indicates Pee Dee belemnite.
}

\section{CONCLUSIONS}

We have constructed a record of $\delta 18 \mathrm{O}_{\mathrm{atm}}$ from the analyses of trapped gases in the Vostok ice core covering the last full glacial cycle. Our $\delta 18 \mathrm{O}_{\mathrm{atm}}$ record is very similar to the seawater $\delta 180$ record over the same period. We interpret this strong similarity as an indication that changes in the $\delta 180$ of seawater, which are known to be associated with changes in the volume of continental ice, have been transmitted to the atmospheric $\mathrm{O}_{2}$ reservoir by photosynthesizing organisms near the surface of the ocean and on the continents. Furthermore, it appears that the major factor influencing $\delta 18 \mathrm{O}_{\mathrm{atm}}$ is the $\delta 18 \mathrm{O}$ of seawater. Based on the similar behavior of these two $\delta 180$ records, we have correlated the $\delta 18 \mathrm{O}_{\text {atm }}$ record from the Vostok ice core into the $\delta 18 \mathrm{O}_{\text {foram }}$ record from V19-30 using an inverse correlation method. Results of the correlation with eight coefficients show that $77 \%$ of the variance is shared between the $\delta 18 \mathrm{O}_{\mathrm{atm}}$ and $\delta 18 \mathrm{O}_{\mathrm{sw}}$ records.

We have utilized the results of the correlation to derive an ice age-depth relation for the Vostok ice core. The record of accumulation rate deduced from our correlated ice age-depth relation differs from that developed by Lorius et al. [1985]. For the correlated ice age-depth curve, the accumulation rate during the last glacial maximum and subsequent deglaciation is as much as $50 \%$ lower than that for the Lorius et al. [1985] age model. For the rest of the core, the correlated record of accumulation rate shows large oscillations which are most likely the result of 1 - to 3-kyr errors in our ice age-depth relation. Such errors may result from errors in (1) the SPECMAP timescale which are calculated to lie between 1.1 and $7.7 \mathrm{kyr}$ [Martinson et al., 1987], (2) estimates of $\Delta$ age which are probably less than $\pm 2 \mathrm{kyr}$, and (3) estimates of the turnover time of atmospheric $\mathrm{O}_{2}$ $( \pm 0.5 \mathrm{kyr})$. Errors may also result from the fact that $\delta 18 \mathrm{O}_{\mathrm{atm}}$ can be influenced by hydrologic and biologic variability in addition to changes in $\delta 18 \mathrm{O}_{\mathrm{sw}}$.

We have investigated the fidelity of the correlated ice age-depth relation by comparing a sea surface temperature record from the southern ocean with the record of Antarctic temperature from the Vostok ice core. The high degree of covariation between these two records supports the use of $\delta 18 \mathrm{O}_{\mathrm{atm}}$ as a proxy for $\delta 18 \mathrm{O}_{\mathrm{sw}}$ and indicates that our correlated agedepth curve for Vostok gives a chronology which is more consistent with the SPECMAP chronology.

Because of poor sample resolution between 400 and 800-m depth and the small changes in $818 \mathrm{O}_{\mathrm{sw}}$ between 25 and $55 \mathrm{ka}$ in the SPECMAP record, we are unable to reliably correlate the two $\delta 180$ records over this time/depth interval. 


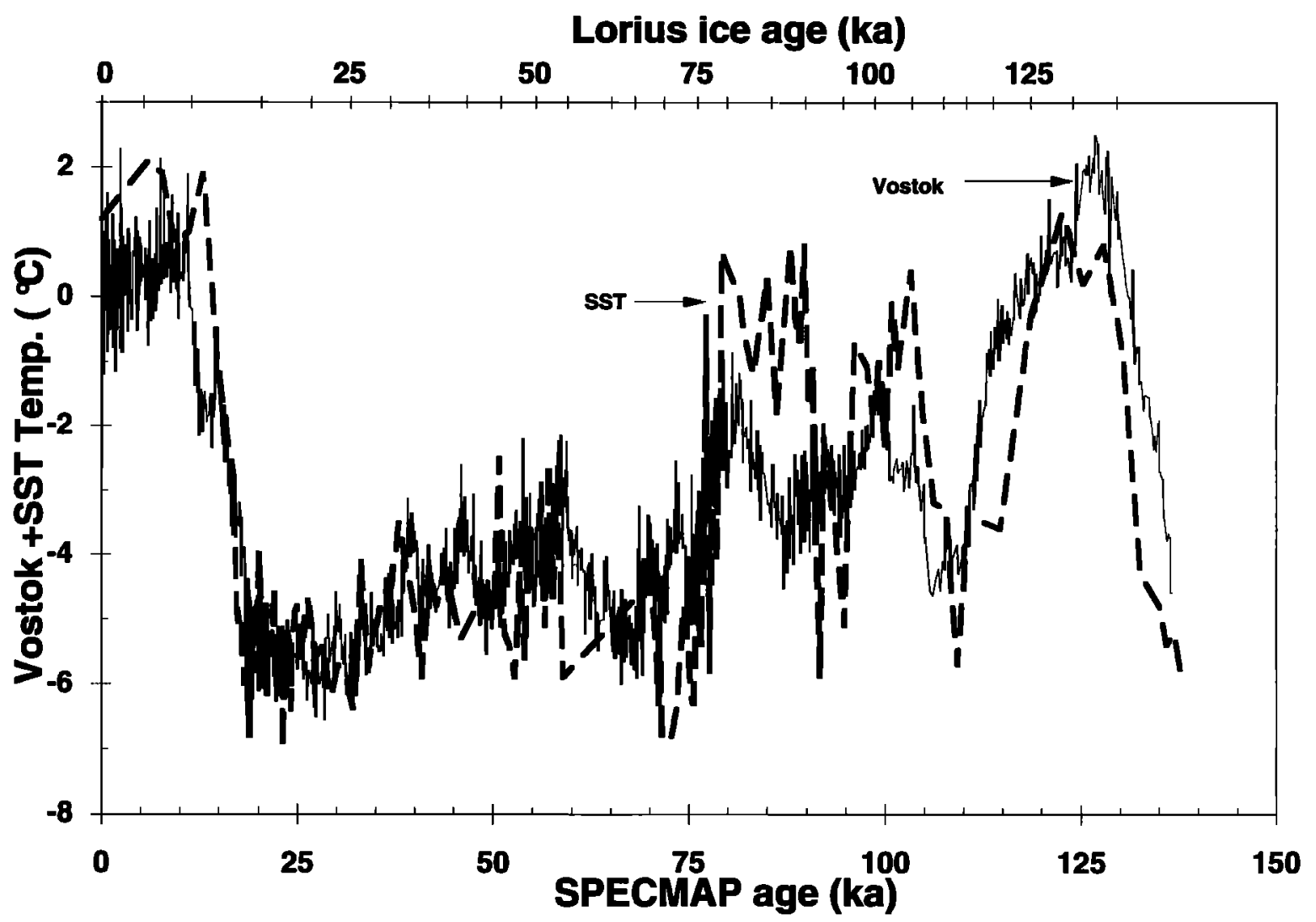

Fig. 8. Records of the Vostok inversion layer temperature and the sea surface temperature (SST) record from MD88-770 plotted on the common temporal framework. The age model for the Vostok inversion layer temperature is our best estimate from Figure 5. The SST record from MD88-770 has a stated uncertainty of $\pm 1{ }^{\circ} \mathrm{C}$. The plot shows a higher degree of similarity than a similar plot made with the Vostok temperature record plotted on the Lorius et al. [1985] chronology. We interpret this result as support for our common temporal framework and therefore our use of $\delta 18 \mathrm{O}_{\mathrm{atm}}$ as a proxy for $\delta 18 \mathrm{O}_{\mathrm{sw}}$. For reference, we have plotted the Lorius et al. [1985] timescale on the upper axis for comparison.

The data and arguments presented here do not give any reason to believe that our chronostratigraphy is any better or worse than that of Lorius et al. [1985]. Future efforts to date Greenland ice cores by counting annual dust layers back through the penultimate deglaciation will help in constructing absolute ice core chronologies. As these "absolute" chronologies become available, we will then be able to establish the relationship between the ice core climate records and any climate records which can be 230Th - 234U dated.

\section{APPENDIX: CONSTRUCTING AN ICE AGE- DEPTH RELATIONSHIP FOR THE VOSTOK ICE CORE}

We used the following approach to calculate an ice age-depth curve for the Vostok ice core.
1. Calculate the correlation gas age of each trapped gas sample in the Vostok ice core. The correlation age is our estimate of the gas age at each sample depth according to the SPECMAP chronology. It is calculated as described in an earlier section.

2 . Calculate the ice age-gas age difference ( $\Delta$ age) for each sample using the densification approach outlined by Sowers et al. [1992]. Briefly, air is assumed to mix rapidly through the firn to the depth of bubble close-off. We assume that the density of ice in the bubble close off region increases with decreasing temperature according to the empirical relation of Martinerie et al. [1992]. The depth at which firn reaches this close off density is given as a function of accumulation rate and temperature by the empirical equations of Herron and Langway [1980]. The ice age at this depth is the ice age-gas age difference and equals the mass of the overburden per unit area divided by the mean accumulation rate. 
This approach gives $\Delta$ age values very close to those calculated using the method of Barnola et al. [1991].

3. Calculate the ice age at each depth by adding $\Delta$ age (calculated in step 2) to the correlation gas age for each depth calculated in step 1 .

4. Calculate ice accumulation rate as a function of depth. Accumulation rate is equal to the slope of the ice age-depth curve divided by the thinning function. The thinning function is defined as the mass per unit area of an annual layer of ice at depth $\mathrm{z}$ in the ice sheet divided by the mass per unit area at the time of deposition. For this calculation we have adopted the thinning function calculated by Ritz [1992].

5. Recalculate $\Delta$ age values for each gas sample using the curve of accumulation rate versus depth calculated in step 4. The point of this recalculation is to estimate $\Delta$ age values which are consistent with the correlated ice age depth relation.

6. Calculate another estimate of the ice age versus depth relation by adding the $\Delta$ age values from step 5 to the correlated gas age at each depth from step 1.

7. Calculate the "correlation ice age versus depth" relation by averaging the ice ages from steps 3 and 6 . We average the ice ages because the iterative procedure described above causes ice ages of some samples to diverge with successive iterations. Our ice age curves did not converge with successive iterations because of errors in the initial correlated gas age-depth relation which are on the order of a few centuries. These errors result in anomalous accumulation rate estimates, which lead to errors in subsequent $\Delta$ age estimates over some portions of the core. We note that ice ages calculated in steps 3 and 6 differ by an average of $0.2 \mathrm{kyr}$, with a maximum difference of $2 \mathrm{kyr}$.

Does our chronology give reasonable curves of accumulation rate? One test of our curve of correlated ice age versus depth is whether or not it provides reasonable estimates of accumulation rate throughout the study period. In Figure 9, we plot

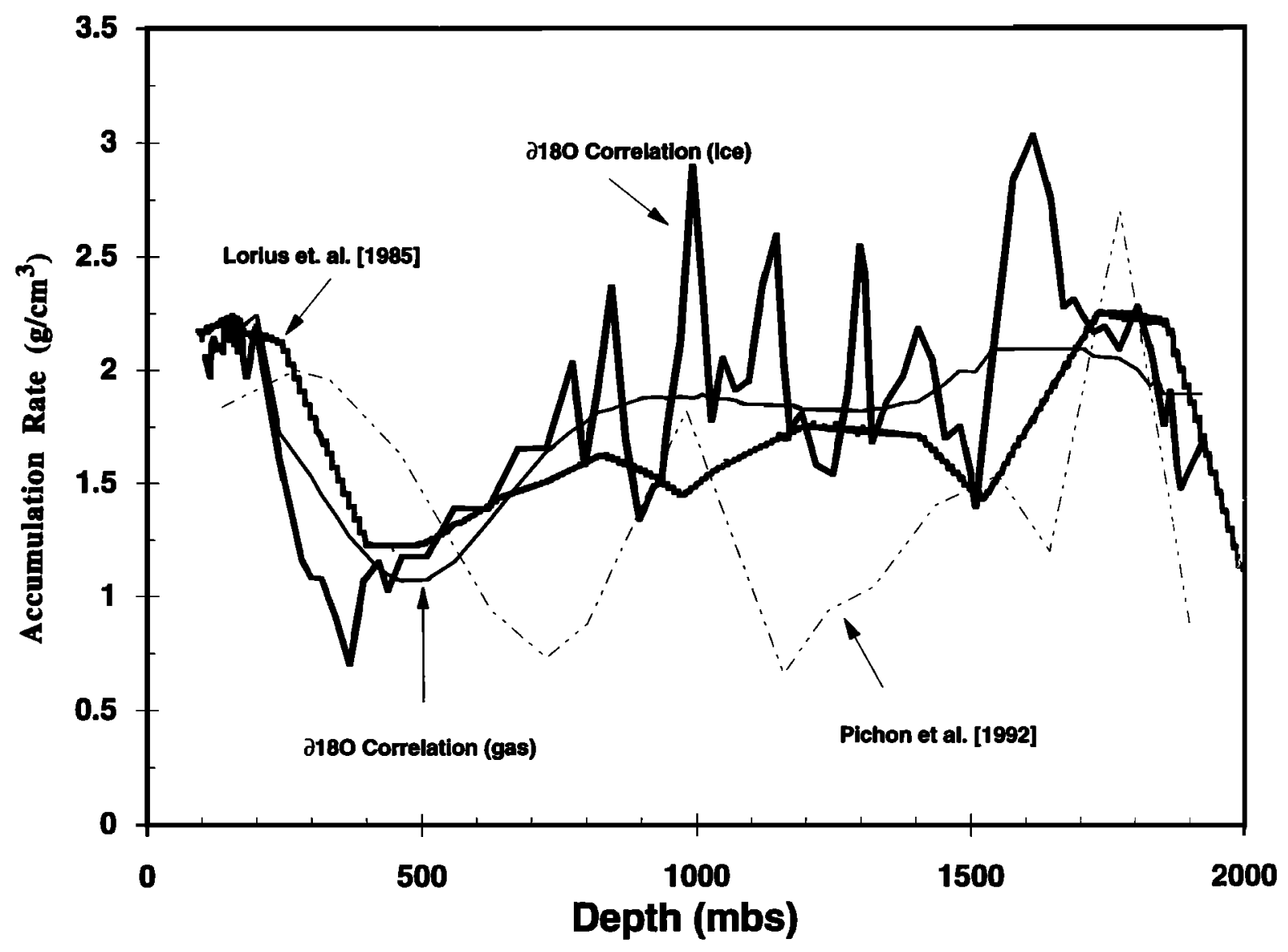

Fig. 9. Records of the surface accumulation rate at Vostok. The thick line is derived from the Lorius et al. [1985] ice age versus depth relation and has been corrected for thinning. The other three curves are from the $\delta 180$ correlation (gas and ice) and the diatom correlation (dashed line). Note the lower accumulation rates calculated from the $\mathbf{8 1 8 0}$-correlated ice age-depth relations between 300 and 500 mbs. Also note the large oscillations in the correlated accumulation rate profile below $700 \mathrm{~m}$ below surface (mbs). 
accumulation rate versus depth for all correlative age models for Vostok. For comparison, we also plot the record of accumulation rate of Lorius et al. [1985]. There are two curves from this study which are marked $\delta 180$ correlation (ice) and $\delta 180$ correlation (gas). The curve labeled $\delta 180$ correlation (gas) is the derivative of the mapping function from the $\delta 18 \mathrm{O}$ of $\mathrm{O}_{2}$ and $\delta 18 \mathrm{O}_{\mathrm{sw}}$ correlation. The curve labeled $\delta 180$ correlation (ice) is the slope of the correlation ice age versus depth relation described in the previous section. Our $\delta 180$ correlation (ice) curve oscillates with a high frequency while the paleoaccumulation record from Lorius et al. [1985] varies slowly. We attribute much of the highfrequency oscillations to small errors in our age estimates.

The high-frequency variations in accumulation rates implied by our chronology (Figure 8) are glaciologically improbable. However, they do not imply large errors in estimated ages. Consider two levels within the core which have been assigned ice ages differing by $2 \mathrm{kyr}$. If the error in the relative ages of these levels is $1.0 \mathrm{kyr}$, then the accumulation rate calculated for the interval in question would be higher than the original value by a factor of 2 or lower by a factor of 0.67 . This range of accumulation rates is comparable to the oscillations in the accumulation rate which we observe in Figure 9. We thus attribute a large portion of the difference between the two curves of accumulation rate shown in Figure 9 to uncertainties in the correlated ice age assigned to each depth. Dating errors could be the result of small errors in the SPECMAP chronology, uncertainties in calculated values of $\Delta$ age, or variations in the $M-D$ effect.

With our chronology, the depth interval between 290 and $360 \mathrm{~m}$ (termination I) corresponds to a period of $6 \mathrm{kyr}$, which is $2.8 \mathrm{kyr}$ longer than that estimated using the flow model approach [Lorius et al., 1985]. The longer duration, inferred from our correlation, corresponds to accumulation rates which are 55\% lower than those estimated by Lorius et al. [1985]. Accumulation rates for this depth interval from the Pichon et al. [1992] chronology are 25\% higher than those inferred from the flow model.

Accumulation rate estimates from the flow model are consistent with $10 \mathrm{Be}$ data for the Vostok ice core if one assumes that the flux of $10 \mathrm{Be}$ to Vostok was about 38\% higher during the last glacial maximum [Raisbeck et al., 1992]. There are three factors which influence the $\left[{ }^{10 \mathrm{Be}}\right]$ in ice at Vostok: (1) the production of $10 \mathrm{Be}$ in the atmosphere (which is dictated by the flux of cosmic rays to the outer portion of the Earth's atmosphere and the intensity of the Earth's geomagnetic field), (2) the accumulation rate at the time of deposition, and (3) variations in local precipitation patterns on the East Antarctic plateau [Raisbeck et al., 1992]. We have estimated the flux of $10 \mathrm{Be}$ to the Vostok area using the accumulation rate curves shown in Figure 9 and the
Vostok [10Be] record from [Raisbeck et al., 1992]. Our calculations indicate that the glacial $10 \mathrm{Be}$ flux to Vostok was $19 \%$ higher for our correlated ice age depth relation, $38 \%$ higher for the Lorius age model, and $83 \%$ higher for the Pichon age model relative to Holocene values. These results are in qualitative agreement with the higher flux of $10 \mathrm{Be}$ to the Pacific Ocean during the same time [Lao et al., 1992]. Furthermore, if we assume that the local precipitation patterns around Vostok remained constant over the last $25 \mathrm{ka}$, then the enhanced flux of $10 \mathrm{Be}$ during glacial periods supports the hypothesis that $10 \mathrm{Be}$ production was enhanced during the last glacial maximum.

Acknowledgments. We would like to thank all the members of the Soviet Antarctic Expeditions, Terres Australes et Antarctiques Françaises (TAAF), Expeditions Polaires Françaises (EPF), and the Office of Polar Programs (NSF) who helped retrieve and transport the Vostok core. J. Orchardo kindly provided his analytical expertise. We are also grateful to J. M. Barnola, E. Bard, C. Lorius, C. Ritz, J. Imbrie, and all the SPECMAP heroes for their useful comments. This research was supported on the American side by the NSF Division of Polar Programs (DPP grants 8820807 and 8822020) and on the French side by TAAF and Programme National d'Etude de la Dynamique du Climat. DGM's research was supported by NSF grant 8312637 (SPECMAP). This is Lamont-Doherty Earth Observatory contribution 5081.

\section{REFERENCES}

Bard, E., B. Hamelin, R. Fairbanks, and A. Zindler, Calibration of the ${ }^{14} \mathrm{C}$ timescale over the past 30,000 years using mass spectrometric U-Th ages from Barbados corals, Nature, 345, 405-410, $1990 a$.

Bard, E., B. Hamelin, and R. G. Fairbanks, U-Th ages obtained by mass spectrometry in corals from Barbados: Sea level during the past 130,000 years, Nature, 346, 456-458, $1990 b$.

Barnola, J. M., D. Raynaud, Y. S. Korotkevich, and C. Lorius, Vostok ice core provides 160,000year record of atmospheric $\mathrm{CO}_{2}$, Nature, 329, 408-414, 1987.

Barnola, J. M., P. Pimienta, D. Raynaud, and Y. S. Korotkevich, $\mathrm{CO}_{2}$-climate relationship as deduced from the Vostok ice core: A reexamination based on new measurements and on a reevaluation of the air dating, Tellus, Ser. B, 43, 83-90, 1991.

Beer, J., S. J. Johnsen, G. Bonnani, R. C. Finkel, C. C. Langway, H. Oeschger, B. Stauffer, M. Suter, and $\mathrm{W}$. Woelfli, ${ }^{10} \mathrm{Be}$ peaks as time markers in polar ice cores, in The Last Deglaciation: Absolute and Radiocarbon Chronologies, edited by E. Bard and W. 
Broecker, pp. 141-153, Springer-Verlag, New York, 1992.

Bender, M. L., L. D. Labeyrie, D. Raynaud, and C. Lorius, Isotopic composition of atmospheric $\mathrm{O}_{2}$ in ice linked with deglaciation and global primary productivity, Nature, 318, 349-352, 1985.

Birchfield, G. E., Changes in deep-ocean water $\delta^{18} \mathrm{O}$ and temperature from the last glacial maximum to the present, Paleoceanography, 2, 431-442, 1987.

Chappell, J., and N. J. Shackleton, Oxygen isotopes and sea level, Nature, 324, 137-140, 1986.

Chappellaz, J., J.-M. Barnola, D. Raynaud, Y. S. Korotkevich, and C. Lorius, Atmospheric CH. record over the last climatic cycle revealed by the Vostok ice core, Nature, 345, 127-131, 1990.

Craig, H., Y. Horibe, and T. A. Sowers, Gravitational separation of gases and isotopes in polar ice caps, Science, 242, 1675-1678, 1988.

Dansgaard, W., H. B. Clausen, N. Gundestrup, S. J. Johnsen, and C. Rygner, Dating and climatic interpretation of two deep Greenland ice cores, in Greenland Ice Core: Geophysics, Geochemistry, and the Environment, Geophys. Monogr. Ser., Vol. 33, edited by C. C. Langway Jr., et al., pp. 71-76, AGU, Washington, D.C., 1985.

Dole, M., The relative atomic weight of oxygen in water and air, J. Am. Chem. Soc., 57, 27312732, 1935.

Dole, M., G. A. Lane, D. P. Rudd, and D. A. Zaukelies, Isotopic composition of atmospheric oxygen and nitrogen, Geochim. Cosmochem. Acta., 6, 65-78, 1954.

Etheridge, D., G. Pearman, and P. Fraser, Changes in tropospheric methane between 1841 and 1978 from a high accumulation rate Antarctic ice core, Tellus, Ser. B, 44, 282-294, 1992.

Fairbanks, R. G., and R. K. Matthews, The marine oxygen isotope record in Pleistocene coral, Barbados, West Indies, Quat. Res. N. Y., 10, 181-196, 1978.

Guiot, J., A. Pons, J. L. de Beaulieu, and M. Reille, A 140,000-year continental climate reconstruction from two European pollen records, Nature, 338, 309-313, 1989.

Hammer, C. U., H. B. Clausen, and H. Tauber, Ice-core dating of the Pleistocene/Holocene boundary applied to a calibration of the ${ }^{14} \mathrm{C}$ time scale, Radiocarbon, 28, 284-291, 1986.

Hays, J. D., J. Imbrie, and N. J. Shackleton, Variations in the Earth's orbit: Pacemaker of the ice ages, Science, 194, 1121-1132, $1976 a$.

Hays, J. D., J. Lozano, N. Shackleton, and G. Irving, Reconstruction of the Atlantic and Western Indian Ocean sectors of the 18,000 B. P. Antarctic Ocean, in Investigation of Late Quaternary Paleoceanography and Paleoclimatology, edited by R. M. Cline, pp. 337-372, Geological Society of America, Boulder, Colo., $1976 b$.

Herron, M. M., and C. C. Langway, Jr., Firn densification: An empirical model, J. Glaciol., 25, 373-385, 1980.

Hovan, S. A., D. K. Rea, and N. G. Pisias, Late Pleistocene continental climate and oceanic variability recorded in northwest Pacific sediments, Paleoceanography, 6, 349-370, 1991.

Howard, W. R., and W. L. Prell, Late Quaternary surface circulation of the Southern Indian Ocean and its relationship to orbital variations, Paleoceanography, 7, 79-118, 1992.

Imbrie, J., J. D. Hays, D. G. Martinson, A. McIntyre, A. C. Mix, J. J. Morley, N. G. Pisias, W. L. Prell, and N. J. Shackleton, The orbital theory of Pleistocene climate: Support from a revised chronology of the marine $\delta^{18} \mathrm{O}$ record, in Milankovitch and Climate, edited by A. Berger et al., pp. 269-305, D. Reidel, Norwell, Mass., 1984.

Johnsen, S. J., H. B. Clausen, W. Dansgaard, K. Fuhrer, N. Gundestrup, C. U. Hammer, P. Iversen, J. Jouzel, B. Stauffer, and J. P. Steffensen, Irregular glacial interstadials recorded in a new Greenland ice core, Nature, 359, 311313, 1992.

Jouzel, J., and L. Merlivat, Deuterium and oxygen 18 in precipitation: Modeling of the isotopic effects during snow formation, $J$. Geophys. Res., 89, 11,749-11,757, 1984.

Jouzel, J., C. Lorius, J. R. Petit, C. Genthon, N. I. Barkov, V. M. Kotlyakov, and V. M. Petrov, Vostok ice core: a continuous isotope temperature record over the last climatic cycle (160,000 years), Nature, 329, 403-407, 1987.

Jouzel, J., G. Raisbeck, J. P. Benoist, F. Yiou, C. Lorius, D. Raynaud, J. R. Petit, N. I. Barkov, Y. S. Korotkevitch, and V. M. Kotlyakov, A comparison of deep Antarctic ice cores and their implications for climate between 65,000 and 15,000 years ago, Quat. Res. N.Y., 31, 135-150, 1989.

Jouzel, J., J. R. Petit, N. I. Barkov, J. M. Barnola, J. Chappellaz, P. Ciais, v. M. Kotkyakov, C. Lorius, V. N. Petrov, D. Raynaud, and C. Ritz, The last deglaciation in Antarctica: Further evidence of a "Younger Dryas" type climatic event., in The Last Deglaciation: Absolute and Radiocarbon Chronologies, edited by E. Bard and W. Broecker, pp. 229-266, Springer-Verlag, New York, 1992.

Jouzel, J., N. I. Barkov, J. M. Barnola, M. Bender, J. Chappellaz, C. Genthon, V. M. Kotlyakov, V. Lipenkov, C. Lorius, J. R. Petit, D. Raynaud, G. Raisbeck, C. Ritz, T. Sowers, M. Stievenard, F. Yiou, and P. Yiou, Vostok ice cores: extending the climatic records over the penultimate glacial period, Nature, 364, 407-412, 1993.

Kotlyakov, V. M., Global changes over the last climatic cycle from Antarctic ice core records, in Glaciers-Ocean-Atmosphere Interactions, edited by V. M. Kotlyakkov, pp. 15-27, International 
Association of Hydrological Sciences, St. Petersburg, Russia, 1990.

Kroopnick, P., and H. Craig, Atmospheric oxygen: Isotopic composition and solubility fractionation, Science, 175, 54-55, 1972.

Kukla, G., and Z. A. An, Loess stratigraphy in central China, Palaeogeogr. Palaeoclimatol. Palaeoecol., 72, 203-225, 1989.

Labeyrie, L. D., J. C. Duplessy, and P. L. Blanc, Variations in mode of formation and temperature of oceanic deep waters over the past 125,000 years, Nature, 327, 477-482, 1987.

Lambeck, K., and M. Nakada, Constraints on the age and duration of the last interglacial period and on sea -level variations, Nature, 357, 125-128, 1992.

Lao, Y., R. F. Anderson, W. S. Broecker, S. E. Trumbore, F. J. Hofmann, and W. Wolfli, Increased production of cosmogenic ${ }^{10} \mathrm{Be}$ during the last glacial maximum, Nature, 357, 576-578, 1992.

Lorius, C., J. Jouzel, C. Ritz, L. Merlivat, N. E. Barkov, and Y. S. Korotkevich, A 150,000-year climatic record from Antarctic ice, Nature, 316, 591-595, 1985.

Lozano, J., and J. D. Hays, Relationship of radiolarian assemblages to sediment types and physical oceanography in the Atlantic and Western Indian ocean sectors of the Antarctic Ocean, in Investigation of Late Quaternary Paleoceanography and Paleoclimatology, edited by J. D. Hays, pp. 303-336, Geological Society of America, Boulder, Colo., 1976.

Lyle, M., Climatically forced organic carbon burial in equatorial Atlantic and Pacific oceans, Nature, 335, 529-532, 1988.

Martinerie, P., D. Raynaud, D. Etheridge, J.-M. Barnola, and D. Mazaudier, Physical and climatic parameters which influence the air content in polar ice, Earth Planet. Sci. Lett., 112, 1-13, 1992.

Martinson, D. G., W. Menke, and P. Stoffa, An inverse approach to signal correlation, $J$. Geophys. Res., 87, 4807-4818, 1982.

Martinson, D. G., N. G. Pisias, J. D. Hays, J. Imbrie, T. C. Moore Jr., and N. J. Shackleton, Age dating and the orbital theory of the ice ages: development of a high-resolution 0 to 300,000year chronostratigraphy, Quat. Res. N.Y., 27, 127, 1987.

Meyer, M. K., Net primary productivity estimates for the last 18,000 years evaluated from simulations by a global climate model, M. S. thesis, Univ. of Wisconsin, Madison, 1988.

Mix, A. C., Influence of productivity variations on long-term atmospheric $\mathrm{CO}_{2}$, Nature, 337, 541544, 1989.

Morita, N., The increased density of air oxygen relative to water oxygen, Nippon Kagaku Kaishi, $56,1291,1935$.
Neftel, A., H. Oeschger, T. Staffelbach, and B. Stauffer, $\mathrm{CO}_{2}$ record in the Byrd ice core 50,0005,000 years BP, Nature, 331, 609-611, 1988.

Petit, J. R., L. Mounier, J. Jouzel, Y. S. Korotkevich, V. I. Kotlyakov, and C. Lorius, Paleoclimatological and chronological implications of the Vostok core dust record, Nature, 343, 56$58,1990$.

Phillpot, H. R., and J. W. Zillman, The surface temperature inversion over the Antarctic continent, J. Geophys. Res., 75, 4161-4169, 1970.

Pichon, J.-J., L. D. Labeyrie, G. Bareille, M. Labracherie, J. Durpat, and J. Jouzel, Surface water temperature changes in the high latitudes of the southern hemisphere over the last glacialinterglacial cycle, Paleoceanography, 7, 289-318, 1992.

Pisias, N. G., D. G. Martinson, T. C. Moore, N. J. Shackleton, W. Prell, and B. Boden, High resolution stratigraphic correlation of benthic oxygen isotopic records spanning the last 300,000 years, Mar. Geol., 56, 119-136, 1984.

Prell, W. L., and J. E. Kutzbach, Monsoon variability over the past 150,000 years, $J$. Geophys. Res., 92, 8411-8425, 1987.

Prell, W. L., J. Imbrie, D. G. Martinson, J. J. Morley, N. G. Pisias, N. J. Shackleton, and H. F. Streeter, Graphic correlation of oxygen isotope stratigraphy: Application to the late Quaternary, Paleoceanography, 1, 137-162, 1986.

Raisbeck, G. M., F. Yiou, D. Bourles, C. Lorius, J. Jouzel, and N. I. Barkov, Evidence for two intervals of enhanced ${ }^{10} \mathrm{Be}$ deposition in Antarctic ice during the last glacial period, Nature, 326, 273-277, 1987.

Raisbeck, G. M., F. Yiou, J. Jouzel, J. R. Petit, N. I. Barkov, and E. Bard, ${ }^{10} \mathrm{Be}$ deposition at Vostok, Antarctica during the last 50,000 years and its relationship to possible cosmogenic production variations during this period, in The Last Deglaciation: Absolute and Radiocarbon Chronologies, edited by E. Bard and W. Broecker, pp. 125-139, Springer-Verlag, New York, 1992.

Raynaud, D., J. Chappellaz, J.-M. Barnola, Y. S. Korotkevich, and $\mathrm{C}$. Lorius, Climatic and $\mathrm{CH}_{4}$ cycle implications of glacial-interglacial $\mathrm{CH}_{4}$ change in the Vostok ice core, Nature, 333, 655$657,1988$.

Reeh, N., S. J. Johnsen, and D. Dahl-Jensen, Dating the Dye 3 deep ice core by flow model Calculations, in Greenland Ice Core: Geophysics, Geochemistry, and the Environment, Geophys. Monogr. Ser., Vol. 33, edited by C. C. Langway Jr., et al., pp. 71-76, AGU, Washington, D.C., 1985.

Ritz, C., Flow modeling the Vostok region, Ph. D. dissertation, Domaine Univ., Grenoble, France, 1992. 
Robin, G. D. Q., Ice cores and climatic changes, Philos. Trans.R. Soc. London, Ser. B, 280, 143168, 1977.

Sarnthein, M., E. Jansen, M. Arnold, J. C. Duplessy, H. Erienkeuser, A. Flatoy, T. Veum, E. Vogelsang, and M. S. Weinelt, $\delta^{18} \mathrm{O}$ time-slice reconstruction of meltwater anomalies at termination $I$ in the North Atlantic between 50 and $80^{\circ} \mathrm{N}$, in The Last Deglaciation: Absolute and Radiocarbon Chronologies, edited by E. Bard and W. S. Broecker, pp. 183-200, Springer-Verlag, New York, 1992.

Schwander, J., The transformation of snow to ice and the occlusion of gases, in The Environmental Record in Glaciers and Ice Sheets, edited by $\mathrm{H}$. Oeschger and C. C. Langway, pp. 53-67, John Wiley, New York, 1989.

Shackleton, N. J., Oxygen isotopes, ice volume and sea level, Quat. Sci. Rev., 6, 183-190, 1987.

Shackleton, N. J., and N. D. Opdyke, Oxygen isotope and paleomagnetic stratigraphy of equatorial Pacific core V28-238: Oxygen isotope temperatures and ice volumes on a $10^{5}$ and $10^{6}$ year scale, Quat. Res. N. Y., 3, 39-55, 1973.

Shackleton, N. J., and N. G. Pisias, Atmospheric carbon dioxide, orbital forcing, and climate, in The Carbon Cycle and Atmospheric $\mathrm{CO}_{2}$ Natural Variations Archean to Present, Geophys. Monogr. Ser., vol. 32, edited by E. T. Sundquist and W. S. Broecker, pp. 303-317, AGU, Washington, DC, 1985 .

Shackleton, N., J. Le, A. Mix, and M. A. Hall, Carbon isotope records from Pacific surface waters and atmospheric carbon dioxide, Quat. Sci. Rev., 11, 387-400, 1992.

Sowers, T. A., M. L. Bender, and D. Raynaud, Elemental and isotopic composition of occluded $\mathrm{O}_{2}$ and $\mathrm{N}_{2}$ in polar ice, J. Geophys. Res., 94, 5137-5150, 1989.

Sowers, T., M. Bender, D. Raynaud, Y. S. Korotkevich, and J. Orchardo, The $\delta^{18} \mathrm{O}$ of atmospheric $\mathrm{O}_{2}$ from air inclusions in the Vostok ice core: Timing of $\mathrm{CO}_{2}$ and ice volume changes during the penultimate deglaciation, Paleoceanography, 6, 679-696, 1991.

Sowers, T., M. Bender, D. Raynaud, and Y. S. Korotkevich, The $\delta^{15} \mathrm{~N}$ of $\mathrm{N}_{2}$ in air trapped in polar ice: A tracer of gas transport in the firn and a possible constraint on ice age-gas age differences, J. of Geophys. Res., 97, 15,683-15,697, 1992.

Stauffer, B., E. Lochbronner, H. Oeschger, and J. Schwander, Methane concentration in the glacial atmosphere was only half that of the preindustrial Holocene, Nature, 332, 812-814, 1988.

Yiou, F., G. M. Raisbeck, D. Bourles, C. Lorius, and N. I. Barkov, ${ }^{10} \mathrm{Be}$ in ice at Vostok Antarctica during the last climatic cycle, Nature, 316, 616617, 1985.

M. Bender and T. Sowers, Graduate School of Oceanography, University of Rhode Island, Narragansett, RI 02882-1197.

J. Jouzel, Laboratoire de Modelisation du Climat et de l'Environnement Batiment 709, Orme des Meriseeirs, CE Saclay 91191 Gif Sur Yvette Cedex, France.

Y. S. Korotkevich, Arctic and Antarctic Research Institute Beringa Street 38, St. Petersburg, Russia. L. Labeyrie, Centre des Faibles Radioactivites Laboratorie Mixte CNRS-CEA Parc du CNRS 91190 Gif Sur Yvette, France.

D. Martinson, Lamont-Doherty Earth Observatory Palisades, NY 10964.

J. J. Pichon, Department Géologie et Océanologie, URA 197, Av des Facultés Université Bordeaux 1, 33405 Talence Cedex France.

D. Raynaud, Laboratoire de Glaciologie et Geophysique de l'Environnement BP 96-38402 St. Martin d'Heres Cedex, France.

(Received January 14, 1993; revised June 17, 1993; accepted August 17, 1993.) 